\title{
Bond characteristics between early aged fly ash concrete and reinforcing steel bar after fire
}

\author{
Qingtao Li $^{\mathrm{a}}$, Xiaohua Huang ${ }^{\mathrm{b}}$, Zhaohui Huang $^{\mathrm{c}}{ }^{*}$, Guanglin Yuan $^{\mathrm{b}}$ \\ ${ }^{\text {a }}$ State Key Laboratory for Geomechanics and Deep Underground Engineering, China University of Mining \\ and Technology, Xuzhou, 221116, China \\ ${ }^{\mathrm{b}}$ School of Mechanics and Civil Engineering, China University of Mining and Technology, Xuzhou, \\ 221116,China \\ ${ }^{\mathrm{c}}$ Department of Mechanical, Aerospace and Civil Engineering, College of Engineering, Design and Physical \\ Science, Brunel University, Uxbridge, Middlesex, UB8 3PH, U.K.
}

\begin{abstract}
In this paper a comprehensive experimental investigation on the residual bond strength between the early aged fly ash concrete and steel ribbed bar after exposed to high temperature has been presented. The research focused on the influences of different temperatures, curing ages, cooling methods and standing times of the specimens after high temperature. A total of 177 pull-out tests were conducted under different conditions. The research indicates that the curing ages of fly ash concrete, exposed temperatures, cooling methods and the standing time of the specimens after cooling have considerable influences on the residual bond strength of fly ash concrete. The research generated a set of reliable and valuable test data for the researchers and practical structural engineers in the field of structural fire engineering.
\end{abstract}

Keywords: Fly ash concrete; Steel ribbed bar; High temperature; Residual bond strength.

*Corresponding author, E-mail address: zhaohui.huang@brunel.ac.uk (Z. Huang) 


\section{RESEARCH HIGHLIGHTS:}

$>$ Conduct 177 pull-out tests on the bond strength of fly ash concrete after fire.

S Study the influence of temperatures on the degradation of the bond strength.

Investigate the bond behaviours of fly ash concrete with different curing ages.

$>$ Understand the impact of different cooling methods on the residual bond strength.

$>$ Provide valuable test data for the fellow researchers and structural engineers. 


\section{Introduction}

Current research indicates that fly ash concrete is more environmental friendly compared to normal Portland cement concrete. Hence, the material has been widely used in the construction industry. Fire is one of the most common disasters to threat public safety and social development. It is possible a fire happened during the construction stage of reinforced concrete buildings due to the problem of construction procedure and management on the construction site. If a fire occurs during construction period it is important to assess the impact of the fire on the residual material strengths of the younger concrete. Therefore, it is needed to assess the safety and reparability of the building structure after a fire. At present there are considerable researches which have been done on the residual strengths of fly ash concrete after high temperatures. The research conducted by Jia et al. [1] indicates that the residual compressive strength, splitting tensile strength of the concrete with large dosage of fly ash are degraded significantly after exposed to elevated temperatures. The content of fly ash within cement has complex influences on the strength degradation of the material at elevated temperatures. The research conducted by Ma [2] points out that the concrete compressive strength and splitting tensile strength of concrete with different dosage of fly ash increase with increasing age of the concrete.

Amrutha et al. [3] conducted an experimental study to investigate the influences of different temperatures on the residual strength of the concrete with high volume of fly ash. Lee [4] also carried out a research on the mechanical properties of fly ash concrete exposed to different high temperatures. Nadeem et al. [5] and Shaikh and Vimonsatit [6] studied the influences of different dosage of fly ash, temperatures and cooling modes on the residual compressive strength, mass loss and other mechanical properties of fly ash concrete. The results show that the reduction of the compressive strength of the concrete under water spray cooling is more significant compared to the concrete using natural air cooling. Khan and Abb [7] studied the impact of high temperatures on the apparent characteristics, mechanical properties and the mass loss of concrete with high volume of fly ash.

Previous researches [8-10] indicated that the bond strength between concrete and reinforcing steel 
bar degraded under fire conditions. Hence, for structural fire engineering design of reinforced concrete buildings it is important to assess the bond strength between concrete and steel bar at elevated temperatures. It is also important to evaluate the residual bond strength of reinforced concrete structural members after fire for structures repairing and strengthening. A number of studies have been done on the bond properties of ordinary reinforced concrete members in fire or after fire. Diederichs and Schneider [11] studied the influences of different types of reinforcing steel bars on the bond characteristics between concrete and steel bar at elevated temperatures. Their results indicated that the bond strength of rib bar decreases as temperature increasing. The degradation ratio of the bond strength has the same order as the reduction of concrete compressive strength at elevated temperatures. At the same temperature the reduction of the bond strength of smooth bar is considerably bigger compared to rib bar. The research conducted by Ferhat and Ruestem [12] shows that the residual bond strength between concrete and steel bar after exposed to high temperature increases with increasing strength of concrete and the anchorage length of steel bar.

Zhu et al. [13] conducted a number of pull-out tests on bond behaviour of reinforced concrete specimens and their results indicated that the bond strength increased when temperature was lower than $150{ }^{\circ} \mathrm{C}$. However, the bond strength reduced significantly at high temperature level. The bond slip at maximum bond stress increased with increasing temperature. Yuan et al. [14] investigated the bond characteristics between concrete and steel bar under different temperatures and cooling methods. Their results indicated that the maximum bond stress decreased and the ultimate bond slip (the slip corresponding to the maximum bond stress) increased as increasing temperature for both natural air cooling and water spray cooling. Compared to natural air cooling, the reduction of bond strength is more significant and the ultimate bond slip is also larger for water spray cooling.

As mentioned above fire incidents may happen during the construction stage of reinforced concrete buildings. Hence, it is important to assess the impact of the fire on the residual material strengths of younger concrete and the bond strength between early aged concrete and reinforcing steel bars. Also for assessing the safety and reparability of the building structure after a fire the recovery of bond 
strength is another important issue needed to be investigated. Previous researches [1-7] indicated that flay ash has lower activity in the early hardening period which affects the speed hydration of products within cement paste. Hence, compared to ordinary concrete, fly ash concrete has lower tensile and compressive strengths at early curing age. As the growth of the concrete age the activity of fly ash increases considerably and the strengths of the concrete increases quickly at the later stage of curing period. At later curing period the compressive strength, tensile strength and toughness of fly ash concrete are considerably higher than ordinary concrete. Also the shrinkage and creep of fly ash concrete are better than ordinary concrete. Therefore, the bond characteristics between early aged fly ash concrete and reinforcing steel bars are different compared to normal concrete.

Due to fly ash concrete has different mechanical properties (compared to normal concrete) it is necessary to study the bond characteristics between fly ash concrete and steel bar at both ambient and elevated temperatures. At present, the majority of the research mainly focuses on the bond behaviours at ambient temperature. Previous researchers conducted a series of pull-out tests to study the bond characteristics between fly ash concrete and steel bar at ambient temperature [15-17]. The results indicated that the bond strength of fly ash concrete increases with increasing concrete curing period. However, according to the authors' knowledge there is very limited research on the residual bond behaviour of fly ash concrete after fire.

Previous researches [12, 14] indicated that the residual bond strength between concrete and reinforcing steel bar after fire is affected by a number of factors, such as concrete compressive and tensile strengths at ambient temperature, concrete curing age, degradation of concrete strengths at elevated temperatures, heating and cooling methods and so on. Therefore, the bond behavior of fly ash concrete is different compared with normal concrete, even both concretes have the same tensile and compressive strengths at ambient temperature.

The main objectives of this research are:

- Conduct a series of pull-out tests to investigate the residual bond strength between fly ash concrete and steel rib bar under different temperatures, and cooling methods. 
- Study the influence of temperatures $\left(150{ }^{\circ} \mathrm{C}, 350{ }^{\circ} \mathrm{C}, 550{ }^{\circ} \mathrm{C}\right)$ on the degradation of the bond strength.

- Investigate the bond behaviours of fly ash concrete with different curing ages ( 7 days, 14 days, 28 days, 56 days and 90 days).

- Understand the impact of different cooling methods (natural air cooling, water spray cooling) and influence of different the standing time of the specimens after cooling on the bond characteristics of fly ash concrete.

- Generate a set of valuable test data for fellow researchers who develop numerical models and practical structural engineers who conduct performance-based structural fire engineering design for reinforced concrete buildings.

\section{Test specimens}

According to Chinese design code for fly ash concrete, the maximum content of fly ash within the concrete should be limited below 30\%. Previous research [5] indicated that the fly ash concrete with $20 \%$ fly ash under fire conditions has good mechanic properties. Therefore, in this research the concrete with $20 \%$ fly ash was adopted to make test specimens. The P.O42.5R ordinary Portland cement manufactured by Huaihai Cement Production was used. The Chemical compositions of the cement are given in Table 1. The fly ash used was the byproducts generated by Xuzhou New Willow Peng Cheng power plant. The chemical compositions of the cement with fly ash are listed in Table 2. And Table 3 presents the physical properties of fly ash. For fly ash concrete, the sand used was medium sand and gravel used was local stone from Xuzhou local area. The water used was ordinary tap water. The procedure of adding fly ash into the concrete followed the recommendation proposed by Chinese code [18]. Table 4 gives the details of the mix proportion of the fly ash concrete and tested compression strength of the fly ash concrete at 28 days was $28 \mathrm{MPa}$.

The pull-out specimen is shown in Fig. 1, in which the concrete block is $150 \mathrm{~mm} \times 150 \mathrm{~mm} \times 150 \mathrm{~mm}$ with one steel rib bar with the diameter of $16 \mathrm{~mm}$ and length of $500 \mathrm{~mm}$. The detailed bar characteristics and material properties are given in Table 5. However, previous research [19] 
indicated that the geometric of steel ribbed bar (such as bar diameter and rib shape) has a considerable influence on the bond strength between concrete and steel bar. In this study the ribbed bar with the diameter of $16 \mathrm{~mm}$ was adopted due to its popularity.

Based on the Chinese code [20], it is recommended that for a pull-out test the embed length of steel bar should not be less than five times of the bar diameter. According to the test results [21], when the relative bond length increases the bond-stress distribution along the bond segment tends to be non-uniform and also the average bond strength reduces. Hence, in this study the bond length of $100 \mathrm{~mm}$ was adopted. Also at both end of the embed length, PVC tubes were used to sleeve the outside of rib bar in order to form unbonded areas (see Fig. 1). One free-end of $50 \mathrm{~mm}$ was used to fix micrometer gauge for measuring the free end slip of the steel bar. Another free-end of $300 \mathrm{~mm}$ was used for applying pull-out force and to fix micrometer gauge for measuring the displacement of the steel frame (see Fig. 3).

Previous research $[7,22]$ indicates that the concrete damage is serious when temperature is over $600{ }^{\circ} \mathrm{C}$. At such high temperature level, the residual compressive strength and bond strength of concrete drops sharply and the structures cannot be meaningfully repaired or strengthened. Hence, three temperatures of $150{ }^{\circ} \mathrm{C}, 350{ }^{\circ} \mathrm{C}$ and $550{ }^{\circ} \mathrm{C}$ were used in the current research. Normally the early strength of fly ash concrete is low and the secondary hydration reacting generally started after 14 days of concrete pouring. When the curing age of 28 days is reached the activity of fly ash effect is still in the initial stage [23]. According to the suggestions proposed by [18] for the determination of the design curing age for fly ash concrete, the following factors are needed to be considered, that is: building types and actual loading time; significant contribution of fly ash to the late strength of concrete. Hence, for the engineering structures above ground the appropriate curing ages are 28 days or 60 days. For the underground engineering structures the appropriate curing ages are 60 days or 90 days.

In recent years, there were considerable numbers of fire accidents happened during the construction period of buildings due to some problems related to the organization and management of construction site. For example, a big fire lasted for 4.5 hours happened at the 23 floor on the 25 
stores reinforced concrete building which was just finished concreting for 3 days in Wuhan, China [24]. The temperature within the concrete floor reached $400{ }^{\circ} \mathrm{C}$. The concrete strength was significantly affected by the fire. Therefore, for assessing the structural safety of the building after fire it is really important to understand the bond strength of such early age of concrete after exposed to fire. Hence, in this research five curing ages were selected, that are 7 days, 14 days, 28 days, 56 days and 90 days.

Also considering the real building fire and firefighting, two cooling methods were used, that are natural air cooling (air cooling) and water spray cooling (water cooling). As mentioned before, three temperatures were used in this research. For understanding the influence of the standing time of the specimens after exposed to high temperatures two types of the pull-out tests were conducted. The first type of the pull-out tests is that the tests were conducted immediately after the specimens were cooled down to room temperature. The second type of the tests is that after the specimens were cooled down to room temperature, the specimens were stored under normal lab's condition for a certain period of time (called standing time) then the pull-out tests were carried out on the specimens. Hence, a total of 59 groups of specimens were needed which included 5 groups of different curing ages at ambient temperature. There were 3 specimens for each test group, hence a total of 177 specimens was tested in this research. Table 6 shows the list of 54 specimens' groups which were exposed to elevated temperatures.

\section{Test procedure}

As shown in Fig. 2, an electrical heating furnace GWD-02A with power of $18 \mathrm{~kW}$ was used in this research. The maximum heating temperature can reach $1100{ }^{\circ} \mathrm{C}$. The furnace has computerized temperature control system. For simulating real fire accident, high heating ratio was adopted. Based on the recommendation from previous research $[25,26]$, high heating rate of $10{ }^{\circ} \mathrm{C} / \mathrm{min}$ was used for all tests. In order to make sure the temperature within the specimens is uniformed distributed, the specimens were heated to the target temperatures $\left(150{ }^{\circ} \mathrm{C}, 350{ }^{\circ} \mathrm{C}, 550{ }^{\circ} \mathrm{C}\right)$ then the target temperatures were maintained for $90 \mathrm{~min}$ before cooled down to ambient temperature. Table 7 shows the heating and maintaining times for three temperature levels. The specimens were heated 
without loading.

After the specimens were cooled down to ambient temperature, then the pull-out tests were conducted. Fig. 3 shows the set-up of pull-out test. As shown in Fig. 5, a PWS500 type electro-hydraulic servo testing machine was used for the tests conducted in this research. According to Chinese code [27] a mixed load-displacement control was adopted for the pull-out tests. At the beginning of the test a load control procedure with $2.5 \mathrm{kN}$ load increment was used. When the maximum pull-out force was reached (the applied load cannot be increased further) then the control procedure was switched to displacement control with the displacement rate of $0.5 \mathrm{~mm} / \mathrm{min}$ until the total de-bonding of the specimens. The load control was switched to displacement control by manually controlling the electro-hydraulic servo testing system.

In this research a DH3818 high-speed synchronous data acquisition system was used to collect the data of slips and pull-out forces. And two YHD-50 displacement meters were used to measure the actual displacements of the steel frame and the free-end of steel bar (see Fig. 3).

After demolding, the specimens were curing to designed curing ages ( 7 to 90 days) then the specimens were heated (see Fig. 4) and cooled by air cooling or water cooling to room temperature. Some of them were directly used for pull-out test after cooling. As presented in Table 6, some of them were stored under natural environmental condition in the structural lab for a certain period of time (standing time) before they were used for pull-out tests (see Fig. 5). Fig. 6 gives the tested residual splitting tensile strengths of flay ash concrete with different curing ages and subjected to different cooling methods after exposed to high temperatures.

\section{Test results}

\subsection{Bond stress and slip curves for the specimens tested without standing time}

The bond stress between fly ash concrete and steel bar can be calculated as:

$$
\tau=\frac{F}{\pi d l}
$$


where:

$$
\begin{aligned}
& \tau=\text { bond stress }(\mathrm{MPa}) \\
& F=\text { Pull-out force }(\mathrm{N}), \\
& d=\text { diameter of steel bar }(\mathrm{mm}), \\
& l=\text { bond length }(\mathrm{mm})
\end{aligned}
$$

In this research in order to generate reliable test data, there are three specimens for each test group. Hence, the test results were the average values of three specimens tested. Figs. 7 to 11 show the tested bond stress and slip curves for the fly ash concrete specimens with different curing ages ( 7 to 90 days) and subjected to different temperatures with both air cooling and water cooling methods. Table 8 gives the ultimate bond-stresses and related ultimate bond-slips for the fly ash concrete specimens which were immediately used for pull-out test after cooling.

\subsubsection{The influence of exposed temperatures on the bond characteristics}

\subsubsection{The ultimate bond-stress $\left(\tau_{\max }\right)$}

Fig. 12 shows the ultimate bond stresses of the fly ash concrete specimens with five different curing ages subjected to air and water cooling after exposed to different temperatures. It is evident that the general trends of the ultimate bond stress of the specimens exposed to different temperatures under air and water cooling are similar. However, compared to air cooling the bond strengths of the specimens were reduced under water cooling condition. Also, the bond strengths were increased with increasing curing ages. It is interesting to note that for the specimens with the curing ages of 7 and 14 days the bond strengths were increased when temperature increased until $150{ }^{\circ} \mathrm{C}$. Then the bond strengths were reduced with temperature further increasing. However, for the specimens with the curing ages of $28,56,90$ days, the bond strengths were increased until $350{ }^{\circ} \mathrm{C}$. After that temperature the bond strengths were reduced as temperature increasing further.

For all specimens with different curing ages the bond strengths were increased when temperatures were increased until $150{ }^{\circ} \mathrm{C}$. This is due to there were some cement paste with insufficient hydration 
reaction at room temperature. When temperature increased the un-hydrated cement particles continued to further hydrate and the hydration products within the cement paste were increased. At the same time free water started to evaporate, this changed the pore size and shape of micro-cracks and accelerated the speed of the cement hydration within the cement paste [28]. This resulted the increased concrete strength. Hence, the bond strength was increased.

However, for the specimens with the curing ages of 7 and 14 days, when temperature was higher than $150{ }^{\circ} \mathrm{C}$, the bond strength reduced as temperature was increased. This is because of the lower hydration speed of fly ash and the surface and free water in the pore, interlayer water and chemical combined water were gradually evaporated [29]. At the same time in the ordinary Portland cement the hydrated calcium silicate and hydrated calcium aluminate become dehydrated [29]. Also the pores' size and cracks within the cement paste were increased due to the steam pressure generated at high temperature. These resulted the degradation of the fly ash concrete strength and reduction of bond strength at high temperature.

For the specimens with the curing ages of 28, 56 and 90 days, the bond strength increased with increasing temperature until $350{ }^{\circ} \mathrm{C}$. This is due to the evaporation of water, the concrete paste was shrinkage resulted from the loss of combined water. This improved the interaction between cement paste and aggregate and enhanced the concrete strength [30]. And the secondary reaction between fly ash and $\mathrm{Ca}(\mathrm{OH})_{2}$ formed hydrated calcium silicate [31] to improve the compactness of concrete. Hence, the bond strength was enhanced. When the temperature reached $350{ }^{\circ} \mathrm{C}$, the ultimate bond stresses of all specimens were decreased with further increasing temperature. After $550{ }^{\circ} \mathrm{C}$, the moisture within the concrete was completely loss. The thermal decomposition of $\mathrm{Ca}(\mathrm{OH})_{2}$ within the concrete happened and the volume of concrete expanded. Also the voids and pores' size within the concrete were increased. The undehydrated particles and composition of quartz in the aggregate were crystalized which resulted significant thermal expansion of the aggregates [30]. Due to the significant different thermal expansions between cement and aggregate, the cracks formed between interfaces of cement and aggregate within the concrete [7]. Therefore, the strength of the concrete was reduced significantly at high temperature. Hence, the bond strength between concrete and steel 
bar was reduced considerably. Another factor is the different thermal expansion of concrete and steel. When the specimens were cooled down after high temperature, the contraction of steel was larger than concrete. So the extrusion of steel bar to the concrete at the interface between concrete and steel bar was reduced significantly after cooling. This further resulted the reduction of bond strength at high temperature [32].

\subsubsection{The ultimate bond slip $\left(s_{\max }\right)$}

The ultimate bond slips of the fly ash concrete specimens with five different curing ages subjected to air and water cooling after exposed to different temperatures are shown in Fig. 13. It can be seen that the relationships between the ultimate bond slip and temperature under air cooling or water cooling are similar.

When temperature reached $150{ }^{\circ} \mathrm{C}$, the ultimate bond slips of all specimens were decreased as temperature increased. This is due to the bond strength was slightly increased, hence the ultimate bond slip was reduced. However, when the temperature was higher than $150{ }^{\circ} \mathrm{C}$, for the specimens with the curing ages of 7 and 14 days, the ultimate bond slips were increased with temperature. But for the specimens with the curing ages of 28, 56, and 90 days, the ultimate bond slips were decreased until the temperature reached $350{ }^{\circ} \mathrm{C}$. After that temperature the ultimate bond slips were increased with the temperature increased. The relationships of ultimate bond slip against temperature presented in Fig. 13 are resulted from the bond strengths changed with temperatures explained in Section 4.2.1.1.

\subsubsection{The influence of cooling methods on the bond characteristics}

\subsubsection{The ultimate bond-stress $\left(\tau_{\max }\right)$}

Fig. 14 shows the impact of different cooling methods on the ultimate bond-stress for the specimens with different curing ages exposed to different temperatures. It can be seen that in general the bond strengths of the specimens using water cooling are relatively smaller than the specimens under air cooling condition. The differences of bond strengths for two methods are increased with increasing temperature. 
The test results show that when temperature reached $150{ }^{\circ} \mathrm{C}$ the bond strength of the specimens with air cooling was increased mainly due to the increment of the mechanical strength of fly ash concrete. This is because of the formation of hydrated calcium silicate and the further hydration of fly ash with cement particles in the formation of calcium silicate hydrate at high temperature [33]. Also the interaction between cement paste and aggregate was enhanced as well. For the specimens with water cooling, on one hand the moisture within the concrete was increased due to watering. This can promote the further hydration within the concrete and the mechanical strength of the concrete was increased. However, on the other hand, the temperature closed to surfaces of the specimens was reduced more extremely due to water cooling. This generated very high temperature gradient within the specimens and high thermal stresses were resulted and more cracks were generated. This significant reduced the concrete strength. Hence, the bond strength of the specimens with water cooling was less than the specimens with air cooling.

When temperature was higher than $350{ }^{\circ} \mathrm{C}$ the temperature gradient within the concrete which resulted from water cooling become a dominant factor to reduce the mechanical strength of the concrete. Also the different thermal expansions between cement paste and aggregate was another factor to influence concrete strength [35]. Hence, the bond strength of the specimens using water cooling was more significant reduced compared to the specimens with air cooling at high temperatures.

\subsubsection{The ultimate bond-slip $\left(s_{\max }\right)$}

The ultimate bond-slips for the specimens with different curing ages under different cooling methods are shown in Fig. 15. It is evident that the influence of cooling methods is similar to the bond strength. In general, the ultimate bond slips of the specimens with water cooling are larger than the specimens using air cooling. The main reason is that the reduction of the bond strength with water cooling is larger than the one with air cooling [36].

\subsection{The influence of standing time on the bond characteristics}

All tested results presented above are related to the specimens which were tested right away after 
they were cooled down to room temperature. In order to investigate the bond characteristics of the specimens with a certain period of standing time after cooling and understanding how the bound strength to recover with time, another series of tests were conducted. In these tests the specimens with four different curing times were heated and cooled down to room temperature then the specimens were stored under normal lab's environment until the total age of 90 days (including the curing ages, see Table 9). After the total age of 90 days was reached the specimen was pull-out tested. Table 9 shows the ultimate bond stresses and ultimate bond slips of the different specimens with different curing ages under different cooling methods. Figs. 16 and 17 show the comparisons of the ultimate bond stresses of the specimens with and without standing times after air or water cooling. Figs. 18 and 19 show the comparisons of the ultimate bond slips of the specimens with and without standing times after air or water cooling.

It can be seen that the standing time has a significant impact on the improving bond strength depending on the curing ages. For example, for the specimens with curing age of 7 days the bond strengths of the specimens with the standing time of 83 days after cooling (the total age was 90 days) is almost three times compared to the specimens without standing time under both air or water cooling. However, the impact gradually reduces when the curing age of the specimens increases. For the specimens with the curing age of 56 days, the bond strength of the specimen with the standing time of 44 days was increased about $20 \%$ compared with the specimens without standing time.

The main reasons for the bond strength to be improved during the standing time is due to very little hydration process of fly ash occurred at early stage of the curing for fly ash concrete. The hydration reaction of fly ash is increased with increasing age of the concrete [23]. Therefore the strength of the fly ash concrete increases with time, especially for very young fly ash concrete, such as the concrete with the curing age of 7 days. Theses influences are reduced considerably for the flay ash concrete with long curing ages, such as 56 days. The increasing strength of the fly ash concrete during standing time helps to improve the bond strength of specimens. This need to be taken into account for assessing the fire safety and repair ability of the concrete structures after a fire. 


\section{Conclusion}

This paper presents a comprehensive experimental investigation on the residual bond strength between the fly ash concrete and steel ribbed bar after exposed to high temperature. The research focused on the influences of different temperatures, curing ages, cooling methods and standing times of the specimens after high temperature. A total of 177 specimens were tested under different conditions. The research generated a set of reliable and valuable test data for fellow researchers and practical structural engineers in the field of structural fire engineering. Based on the test results some conclusions can be drawn as the following:

- The curing age of the fly ash concrete has significant influence on the bond strength between the concrete and steel ribbed bar. The bond strength is increased with increasing curing age of the concrete.

- For the specimens with the curing ages of 7 and 14 days, when the exposed temperature is lower than $150{ }^{\circ} \mathrm{C}$ the residual bond strength of the fly ash concrete is increased with temperature. However, when temperature is higher than $150{ }^{\circ} \mathrm{C}$, the bond strength of the concrete will reduce as temperature increasing.

- For the specimens with the curing ages of 28, 56, and 90 days, when the exposed temperature is lower than $350{ }^{\circ} \mathrm{C}$ the residual bond strength of the fly ash concrete is increased with temperature. However, when temperature is higher than $350{ }^{\circ} \mathrm{C}$, the bond strength of the concrete will reduce as temperature increasing.

- The residual bond strength of the specimens using water cooling is more significant reduced compared to the specimens with air cooling at high temperatures.

- The standing time of the specimens after cooling has a significant impact on the residual bond strength of the concrete depending on the curing ages. The lower curing age the higher improvement of residual bond strength for the specimens with standing time after exposed to high temperature. 


\section{Acknowledgements}

The authors wish to thank the financial support by the Fundamental Research Funds for the Central Universities with Grant No. 2013QNB20.

\section{References}

[1] F. Jia, Y. Cui, Y. Sun, Y. Chen, Effects of elevated temperatures on the mechanical properties of high fly ash content concrete. Journal of Xi'an University of Architecture \& Technology (Natural Science Edition) 43(3) (2011) 581-587 (in Chinese).

[2] H. Ma, Relationship between mechanical property and curing age of fly ash concrete after high temperature, Industrial Construction 43(1) (2013) 80-84 (in Chinese).

[3] Amrutha, G. Nayak, M. Narasimhan, S. Rajeeva. High temperature performance of self-compacting high-volume fly ash concrete mixes, Journal of Structural Fire Engineering 2(2) (2011) 81-90.

[4] S. J. Lee, Mechanical properties of high performance concrete subjected to high temperature as a function of fly-ash and fiber addition, Advanced Materials Research 912-914 (2014) 227-230.

[5] A. Nadeem, S.A. Memon, T. Y. Lo, The performance of fly ash and metakaolin concrete at elevated temperatures. Construction and Building Materials 62 (2014) 67-76.

[6] F. U. A. Shaikh, V. Vimonsatit, Effect of cooling methods on residual compressive strength and cracking behavior of fly ash concretes exposed at elevated temperatures, Fire and Materials 40 (2016) 335-350.

[7] M. S. Khan, H. Abbas, Effect of elevated temperature on the behavior of high volume fly ash concrete, Structural Engineering 19(6) (2015) 1825-1831.

[8] T. Pothisiri and P. Panedpojaman, Modeling of bonding between steel rebar and concrete at elevated temperature, Construction and Building Materials, 27 (2012) 130-140.

[9] J. Xiao, Y. Hou, Z. Huang. Beam test on bond behavior between high-grade rebar and high-strength concrete after elevated temperatures, Fire Safety Journal 69 (2014) 23-35.

[10]E.L.-V. Hlavicka, Bond after fire, Construction and Building Materials 132 (2017) 210-218.

[11]U. Diederichs, U. Schneider, Bond strength at high temperatures, Magazine of Concrete Research 33 (1981) 75-84.

[12]B. A. Ferhat, G. Ruestem. Residual bond strength between steel bars and concrete after elevated temperatures, Fire Safety Journal 44(6) (2009) 854-859.

[13]B. Zhu, Z. Lu, K. Hu, The constitutive relationship of concrete and steel bar under high temperatures, Sichuan Building Science 1(37-43) (1990) (in Chinese).

[14]G. Yuan, C. Guo, Q. Li, Z. Lv, Bond damage in reinforced concrete caused by cooling after high temperature, Journal of China University of Mining \& Technology 34(5) (2005) 605-608 (in Chinese). 
[15]J. Zhuang J. Zheng Experiment study of fly ash content influence on bond performance between reinforcement and self-compacting concrete, Journal of Fuzhou University (Natural Science Edition), 41(2) (2013) 229-234 (in Chinese).

[16]X. Hu, D. Niu, Y. Zhang, Experimental research on bond performance of early-age fly ash concrete, Journal of Building Structures 34(3) (2013) 152-157 (in Chinese).

[17]Dirk Weiae, Klaus Holschemacher, Some Aspects about the Bond of Reinforcement in Ultra High Strength Concrete, LBCCR No.8, 2003, pp251-263.

[18]GB/T 50146-2014 Technical Code for Application of Fly Ash Concrete, Ministry of Housing and Urban-rural Development of China, China Planning Press, Beijing, 2014.

[19]J. Khalaf, Z. Huang, and M. Fan, Analysis of bond-slip between concrete and steel bar in fire, Computers \& Structures 162 (2016) 1-15.

[20]GB 50152-92 Standard for Test Method of Concrete Structures, Ministry of Housing and Urban-rural Development of China, Sun Yat-Sen University Press, Guangzhou, 1992.

[21]C. O. Orangun, J. O. Jirsa, J. E. Breen, A Reevaluation of Test Data on Development Length and Splices, ACI, 1977.

[22]N. Li, X. Shi, M. Xiao, Experimental investigation on compressive strength decaying behaviors of concrete after elevated temperature, Building Science 23(9) (2007) 58-61 (in Chinese).

[23]P. K. Mehta. High-performance, High-volume Fly Ash Concrete for Sustainable Development, in: Edited by J. Ke, Proceedings of the International Workshop on Sustainable Development and Concrete Technology, Beijing, China, 2004, pp. 3-14.

[24]L. Zhang, X. Dong and J. Xu, Reinforcing and retrofitting of an office building in Wuhan Optical Valley after fire accident, Building Structure, 37(9) (2007) 132-133. (in Chinese)

[25] S. Aydm and B. Baradan, Effect of pumice and fly ash incorporation on high temperature resistance of cement based mortars, Cement \& Concrete Research, 2007, 37:988-995.

[26] G.T.G. Mohamedbhai, Effect of exposure time and rates of heating and cooling on residual strength of heated concrete, Magazine of Concrete Research 38 (136) (1986) 151-158.

[27]GB/T 50152-2012 Standard for Test Method of Concrete Structures, Ministry of Housing and Urban-rural Development of China, China Architecture \& Building Press, Beijing, 2012.

[28]B. Chen, C. Li, L. Chen, Experimental study of mechanical properties of normal-strength concrete exposed to high temperatures at an early age, Fire Safety Journal $44(, 2009) 997-1002$.

[29]L. Chen, B. Li, T. Teng, T. Chen, The analysis about high temperature mechanical performance of concrete, Concrete 7 (2003) 26-28 (in Chinese).

[30]L. Liu, L. Lv, Z. Liu, H. Wang, Investigation on the mechanical behavior of concrete at and after elevated temperature, Building Science 21(3) (2005) 16-20 (in Chinese).

[31]K. W. Nasser and H. M. Marzouk, Properties of mass concrete containing fly ash at high temperatures, ACI Journal, 76(4) (1979) 537-551. 
[32] D. Xie and Z. Qian, Research on bond and tension of concrete after high temperature. Journal of Zhejiang University (Natural Science Edition) 32(5) (1998) 597-602 (in Chinese).

[33]H. Tanyildizi and A. Coskun, The effect of high temperature on compressive strength and splitting tensile strength of structural lightweight concrete containing fly ash, Construction and Building Materials 22(11) (2008) 2269-2275.

[34]Bingol AF, Gul R. Effect of elevated temperatures and cooling regimes on normal strength concrete [J]. Fire and Materials, 2009, 33:79-88.

[35]C. S. Poon, S. Azhar, M. Anson, Y. L. Wong, Comparison of the strength and durability performance of normal- and high-strength pozzolanic concretes at elevated temperatures, Cement and Concrete Research 31 (2001) 1291-1300.

[36]A. Mendes, G. S. Jay, F. Collins, Effects of slag and cooling method on the progressive deterioration of concrete after exposure to elevated temperatures as in a fire event, Materials and Structures 44(3) (2011) 709-718. 


\section{Captions of Figures and tables}

Table 1 Chemical composition of P.O42.5R ordinary Portland cement.

Table 2 Chemical composition of the cement with fly ash.

Table 3 Physical properties of fly ash.

Table 4 Mix design of the fly ash concrete $\left(\mathrm{kg} / \mathrm{m}^{3}\right)$.

Table 5 Detailed bar characteristics and properties.

Table 6 List of 54 specimens' groups which were exposed to elevated temperatures.

Table 7 Heating procedure.

Table 8 Ultimate bond stresses and displacements of the specimens without standing time.

Table 9 Ultimate bond stress and displacement of specimens with standing time after fire.

Fig. 1 Pull-out specimen (all dimensions in $\mathrm{mm}$ ).

Fig. 2 Electrical furnace and control device.

Fig. 3 Experimental set-up for pull-out test.

Fig. 4 Heating on specimen.

Fig. 5 Loading on specimen.

Fig. 6 Residual splitting tensile strengths of flay ash concrete with different curing ages and subjected to different cooling methods after exposed to high temperatures.

Fig. 7 Bond-slip curves of the specimens with 7 days curing age under different heating and cooling conditions.

Fig. 8 Bond-slip curves of the specimens with 14 days curing age under different heating and cooling conditions.

Fig. 9 Bond-slip curves of the specimens with 28 days curing age under different heating and cooling conditions.

Fig. 10 Bond-slip curves of the specimens with 56 days curing age under different heating and cooling conditions.

Fig. 11 Bond-slip curves of the specimens with 90 days curing age under different heating and cooling conditions.

Fig. 12 The ultimate bond stresses of the specimens with different curing ages $(\mathrm{d}=$ days $)$ against temperature.

Fig. 13 The ultimate bond slips of the specimens with different curing ages $(\mathrm{d}=$ days $)$ against 
temperature.

Fig. 14 Influences of cooling methods on the ultimate bond stresses of the specimens under different conditions.

Fig. 15 Influences of cooling methods on the ultimate bond slips of the specimens under different conditions.

Fig. 16 Influences of standing times on the ultimate bond stresses of the specimens exposed to different temperatures under air cooling (No = no standing time; Yes = have standing time).

Fig. 17 Influences of standing times on the ultimate bond stresses of the specimens exposed to different temperatures under water cooling $(\mathrm{No}=$ no standing time; Yes $=$ have standing time $)$.

Fig. 18 Influences of standing times on the ultimate bond slips of the specimens exposed to different temperatures under air cooling (No = no standing time; Yes $=$ have standing time).

Fig. 19 Influences of standing times on the ultimate bond slips of the specimens exposed to different temperatures under water cooling $(\mathrm{No}=$ no standing time; Yes $=$ have standing time $)$. 


\section{Tables}

Table 1 Chemical composition of P.O42.5R ordinary Portland cement

\begin{tabular}{lccccccccccc}
\hline Composition & $\mathrm{Na}_{2} \mathrm{O}$ & $\mathrm{MgO}$ & $\mathrm{Al}_{2} \mathrm{O}_{3}$ & $\mathrm{SiO}_{2}$ & $\mathrm{~K}_{2} \mathrm{O}$ & $\mathrm{CaO}$ & $\mathrm{Fe}_{2} \mathrm{O}_{3}$ & $\mathrm{MnO}$ & $\mathrm{TiO}_{2}$ & $\mathrm{P}_{2} \mathrm{O}_{5}$ & $\mathrm{SO}_{3}$ \\
\hline $\begin{array}{c}\text { Content } \\
\text { (wt. \%) }\end{array}$ & 0.17 & 2.5 & 7.0 & 22.5 & 0.78 & 59 & 3.3 & 0.33 & 0.31 & 0.1 & 1.8 \\
\hline
\end{tabular}

Table 2 Chemical composition of the cement with fly ash

\begin{tabular}{cccccccccccc}
\hline Composition & $\mathrm{Na}_{2} \mathrm{O}$ & $\mathrm{MgO}$ & $\mathrm{Al}_{2} \mathrm{O}_{3}$ & $\mathrm{SiO}_{2}$ & $\mathrm{~K}_{2} \mathrm{O}$ & $\mathrm{CaO}$ & $\mathrm{Fe}_{2} \mathrm{O}_{3}$ & $\mathrm{MnO}$ & $\mathrm{TiO}_{2}$ & $\mathrm{P}_{2} \mathrm{O}_{5}$ & $\mathrm{SO}_{3}$ \\
\hline $\begin{array}{c}\text { Content } \\
\text { (wt. \%) }\end{array}$ & 0.15 & 0.75 & 32.8 & 54.5 & 1.4 & 2.7 & 4.1 & 0.02 & 1.3 & 0.15 & 0.4 \\
\hline
\end{tabular}

Table 3 Physical properties of fly ash

\begin{tabular}{|c|c|c|c|c|}
\hline Type & $\begin{array}{l}\text { Fineness ( } 45 \mu \mathrm{m} \text { square hole } \\
\text { sieve remain, wt. } \% \text { ) }\end{array}$ & $\begin{array}{l}\text { Loss on ignition } \\
\qquad \text { (wt. \%) }\end{array}$ & $\begin{array}{l}\text { Ratio of water } \\
\text { demand (wt. \%) }\end{array}$ & $\begin{array}{r}\text { Content of sulphur } \\
\text { trioxide (wt. \%) }\end{array}$ \\
\hline Class I & 10 & 3 & 92 & 1.6 \\
\hline
\end{tabular}

Table 4 Mix design of the fly ash concrete $\left(\mathrm{kg} / \mathrm{m}^{3}\right)$

\begin{tabular}{c|c|c|c|c|c|c}
\hline Cement & Fly ash & Water & Fine aggregate & $\begin{array}{c}\text { Coarse } \\
\text { aggregate }\end{array}$ & Admixture & $\begin{array}{c}\text { Water cement } \\
\text { ratio }\end{array}$ \\
\hline 240 & 72 & 180 & 779 & 1095 & 3 & 0.58 \\
\hline
\end{tabular}


Table 5 Detailed bar characteristics and properties

\begin{tabular}{ll}
\hline \multicolumn{1}{c}{ Nominal diameter, $\mathrm{d}_{\mathrm{b}}(\mathrm{mm})$} & 16 \\
\hline Core diameter, $\mathrm{D}(\mathrm{mm})$ & 15.4 \\
Average rib depth, $\mathrm{h}_{\mathrm{r}}(\mathrm{mm})$ & 1.4 \\
Base rib width, $\mathrm{a}_{\mathrm{r}}(\mathrm{mm})$ & 3.6 \\
Top rib width, $\mathrm{b}_{\mathrm{r}}(\mathrm{mm})$ & 0.9 \\
Rib spacing, $\mathrm{s}_{\mathrm{r}}(\mathrm{mm})$ & 11.0 \\
Rib face angle, $\Theta\left({ }^{\circ}\right)$ & 49 \\
Relative rib area, $\mathrm{R}_{\mathrm{r}}(-)$ & 0.08 \\
Cross-sectional area, $\mathrm{A}_{\mathrm{b}}(\mathrm{mm})$ & 201.1 \\
Nominal Young modulus, $\mathrm{E}_{\mathrm{s}}(\mathrm{GPa})$ & 200 \\
Measured yield strength, $\mathrm{f}_{\mathrm{y}}(\mathrm{MPa})$ & 407 \\
Measured ultimate strength, $\mathrm{f}_{\mathrm{y}}(\mathrm{MPa})$ & 512 \\
\hline
\end{tabular}

Table 6 List of 54 specimens' groups which were exposed to elevated temperatures

\begin{tabular}{|c|c|c|c|c|c|c|c|c|c|}
\hline Curing age (day) & 7 & 14 & 28 & 56 & 90 & 7 & 14 & 28 & 56 \\
\hline Standing time (day) & 0 & 0 & 0 & 0 & 0 & 82 & 76 & 62 & 34 \\
\hline $\begin{array}{c}\text { Concrete age at test } \\
\text { (day) }\end{array}$ & 7 & 14 & 28 & 56 & 90 & 90 & 90 & 90 & 90 \\
\hline $150^{\circ} \mathrm{C}$, Air cooling & $15 \mathrm{~A} 7$ & $15 \mathrm{~A} 14$ & $15 \mathrm{~A} 28$ & $15 \mathrm{~A} 56$ & $15 \mathrm{~A} 90$ & $15 \mathrm{~A} 7 \mathrm{C}$ & $15 \mathrm{~A} 14 \mathrm{C}$ & $15 \mathrm{~A} 28 \mathrm{C}$ & $15 \mathrm{~A} 56 \mathrm{C}$ \\
\hline $\begin{array}{c}150^{\circ} \mathrm{C}, \text { water } \\
\text { cooling }\end{array}$ & $15 \mathrm{~W} 7$ & $15 \mathrm{~W} 14$ & $15 \mathrm{~W} 28$ & $15 \mathrm{~W} 56$ & $15 \mathrm{~W} 90$ & $15 \mathrm{~W} 7 \mathrm{C}$ & $15 \mathrm{~W} 14 \mathrm{C}$ & $15 \mathrm{~W} 28 \mathrm{C}$ & $15 \mathrm{~W} 56 \mathrm{C}$ \\
\hline $350^{\circ} \mathrm{C}$, Air cooling & $35 \mathrm{~A} 7$ & $35 \mathrm{~A} 14$ & $35 \mathrm{~A} 28$ & $35 \mathrm{~A} 56$ & $35 \mathrm{~A} 90$ & $35 \mathrm{~A} 7 \mathrm{C}$ & $35 \mathrm{~A} 14 \mathrm{C}$ & $35 \mathrm{~A} 28 \mathrm{C}$ & $35 \mathrm{~A} 56 \mathrm{C}$ \\
\hline $\begin{array}{l}350^{\circ} \mathrm{C} \text {, water } \\
\text { cooling }\end{array}$ & $35 \mathrm{~W} 7$ & $35 \mathrm{~W} 14$ & $35 \mathrm{~W} 28$ & $35 \mathrm{~W} 56$ & $35 \mathrm{~W} 90$ & $35 \mathrm{~W} 7 \mathrm{C}$ & $35 \mathrm{~W} 14 \mathrm{C}$ & $35 \mathrm{~W} 28 \mathrm{C}$ & $35 \mathrm{~W} 56 \mathrm{C}$ \\
\hline $550^{\circ} \mathrm{C}$, Air cooling & $55 \mathrm{~A} 7$ & $55 \mathrm{~A} 14$ & $55 \mathrm{~A} 28$ & $55 \mathrm{~A} 56$ & $55 \mathrm{~A} 90$ & $55 \mathrm{~A} 7 \mathrm{C}$ & $55 \mathrm{~A} 14 \mathrm{C}$ & $55 \mathrm{~A} 28 \mathrm{C}$ & $55 \mathrm{~A} 56 \mathrm{C}$ \\
\hline $\begin{array}{l}550^{\circ} \mathrm{C} \text {, water } \\
\text { cooling }\end{array}$ & $55 \mathrm{~W} 7$ & $55 \mathrm{~W} 14$ & $55 \mathrm{~W} 28$ & $55 \mathrm{~W} 56$ & $55 \mathrm{~W} 90$ & $55 \mathrm{~W} 7 \mathrm{C}$ & $55 \mathrm{~W} 14 \mathrm{C}$ & $55 \mathrm{~W} 28 \mathrm{C}$ & $55 \mathrm{~W} 56 \mathrm{C}$ \\
\hline
\end{tabular}

A: air cooling; W: water cooling; C: Re-curing after heating

Table 7 Heating procedure

\begin{tabular}{ccc}
\hline Temperature $\left({ }^{\circ} \mathrm{C}\right)$ & Heating time $(\mathrm{min})$ & Maintaining time $(\mathrm{min})$ \\
\hline 150 & 15 & 90 \\
350 & 30 & 90 \\
550 & 45 & 90 \\
\hline
\end{tabular}


Table 8 Ultimate bond stresses and displacements of the specimens without standing time

\begin{tabular}{|c|c|c|c|c|c|}
\hline \multirow{2}{*}{$\begin{array}{l}\text { Curing age } \\
\text { (day) }\end{array}$} & \multirow{2}{*}{$\begin{array}{c}\text { Temperature } \\
\left({ }^{\circ} \mathrm{C}\right)\end{array}$} & \multicolumn{2}{|c|}{ Ultimate bond stress (MPa) } & \multicolumn{2}{|c|}{ Ultimate bond slip (mm) } \\
\hline & & Air cooling & Water cooling & Air cooling & Water cooling \\
\hline \multirow{4}{*}{7} & 20 & \multicolumn{2}{|c|}{3.42} & \multicolumn{2}{|c|}{1.35} \\
\hline & 150 & 4.09 & 3.64 & 1.13 & 1.21 \\
\hline & 350 & 3.16 & 2.71 & 1.42 & 1.56 \\
\hline & 550 & 2.38 & 1.91 & 2.26 & 1.93 \\
\hline \multirow{4}{*}{14} & 20 & \multicolumn{2}{|c|}{4.25} & \multicolumn{2}{|c|}{1.29} \\
\hline & 150 & 5.12 & 4.64 & 1.02 & 1.07 \\
\hline & 350 & 4.11 & 3.45 & 1.31 & 1.40 \\
\hline & 550 & 3.03 & 2.37 & 2.12 & 2.21 \\
\hline \multirow{4}{*}{28} & 20 & \multicolumn{2}{|c|}{6.74} & \multicolumn{2}{|c|}{1.16} \\
\hline & 150 & 7.53 & 6.95 & 0.98 & 1.03 \\
\hline & 350 & 8.38 & 7.15 & 0.89 & 0.97 \\
\hline & 550 & 4.79 & 3.76 & 2.06 & 2.15 \\
\hline \multirow{4}{*}{56} & 20 & \multicolumn{2}{|c|}{9.02} & \multicolumn{2}{|c|}{1.03} \\
\hline & 150 & 10.16 & 9.89 & 0.88 & 0.95 \\
\hline & 350 & 11.01 & 10.31 & 0.75 & 0.87 \\
\hline & 550 & 6.59 & 5.04 & 1.84 & 2.12 \\
\hline \multirow{4}{*}{90} & 20 & \multicolumn{2}{|c|}{10.37} & \multicolumn{2}{|c|}{0.87} \\
\hline & 150 & 11.72 & 11.02 & 0.69 & 0.75 \\
\hline & 350 & 12.64 & 11.38 & 0.62 & 0.69 \\
\hline & 550 & 7.52 & 5.79 & 1.51 & 1.81 \\
\hline
\end{tabular}


Table 9 Ultimate bond stress and displacement of specimens with standing time after fire

\begin{tabular}{|c|c|c|c|c|c|c|}
\hline \multirow{2}{*}{$\begin{array}{l}\text { Curing } \\
\text { age (day) }\end{array}$} & \multirow{2}{*}{$\begin{array}{c}\text { Temperature } \\
\left({ }^{\circ} \mathrm{C}\right)\end{array}$} & \multirow{2}{*}{$\begin{array}{l}\text { Standing } \\
\text { time (day) }\end{array}$} & \multicolumn{2}{|c|}{$\begin{array}{l}\text { Ultimate bond stress } \\
(\mathrm{MPa})\end{array}$} & \multicolumn{2}{|c|}{ Ultimate bond slip (mm) } \\
\hline & & & $\begin{array}{c}\text { Air } \\
\text { cooling }\end{array}$ & $\begin{array}{l}\text { Water } \\
\text { cooling }\end{array}$ & $\begin{array}{c}\text { Air } \\
\text { cooling }\end{array}$ & Water cooling \\
\hline \multirow{3}{*}{7} & 150 & & 11.88 & 11.36 & 0.64 & 0.70 \\
\hline & 350 & 83 & 9.89 & 9.44 & 0.82 & 0.90 \\
\hline & 550 & & 7.94 & 6.84 & 1.41 & 1.66 \\
\hline \multirow{3}{*}{14} & 150 & & 11.41 & 10.99 & 0.70 & 0.76 \\
\hline & 350 & 76 & 9.72 & 9.29 & 0.84 & 0.93 \\
\hline & 550 & & 7.38 & 6.12 & 1.43 & 1.75 \\
\hline \multirow{3}{*}{28} & 150 & & 12.4 & 11.51 & 0.64 & 072 \\
\hline & 350 & 62 & 12.89 & 12.03 & 0.59 & 0.67 \\
\hline & 550 & & 8.39 & 7.21 & 1.35 & 1.59 \\
\hline \multirow{3}{*}{56} & 150 & & 11.93 & 10.95 & 0.68 & 0.75 \\
\hline & 350 & 34 & 12.66 & 11.98 & 0.61 & 0.71 \\
\hline & 550 & & 7.58 & 6.43 & 1.48 & 1.80 \\
\hline
\end{tabular}




\section{Figures}

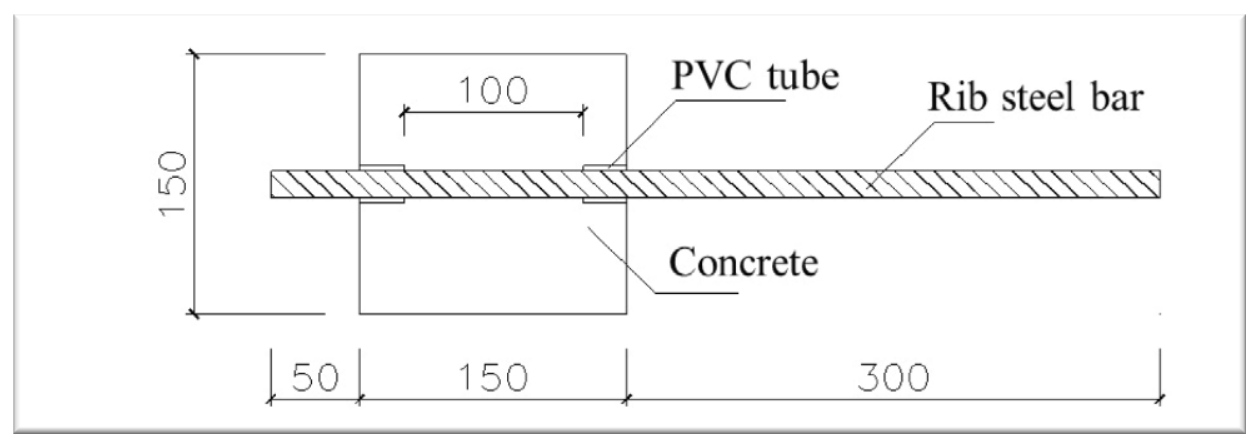

Fig. 1 Pull-out specimen (all dimensions in $\mathrm{mm}$ ).

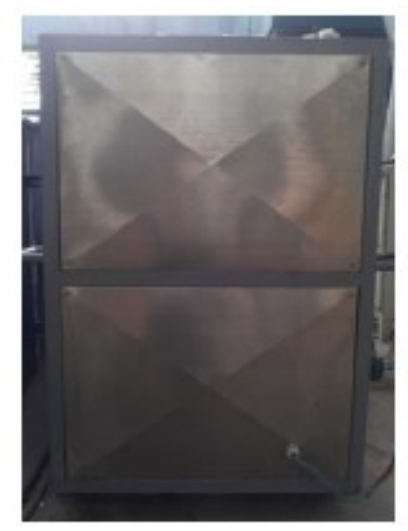

(a) Electrical furnace

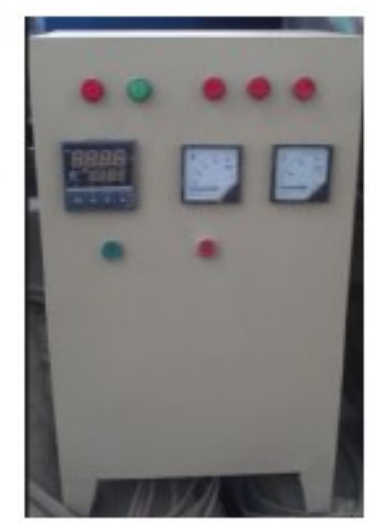

(b) Temperature control cabinet

Fig. 2 Electrical furnace and control device. 


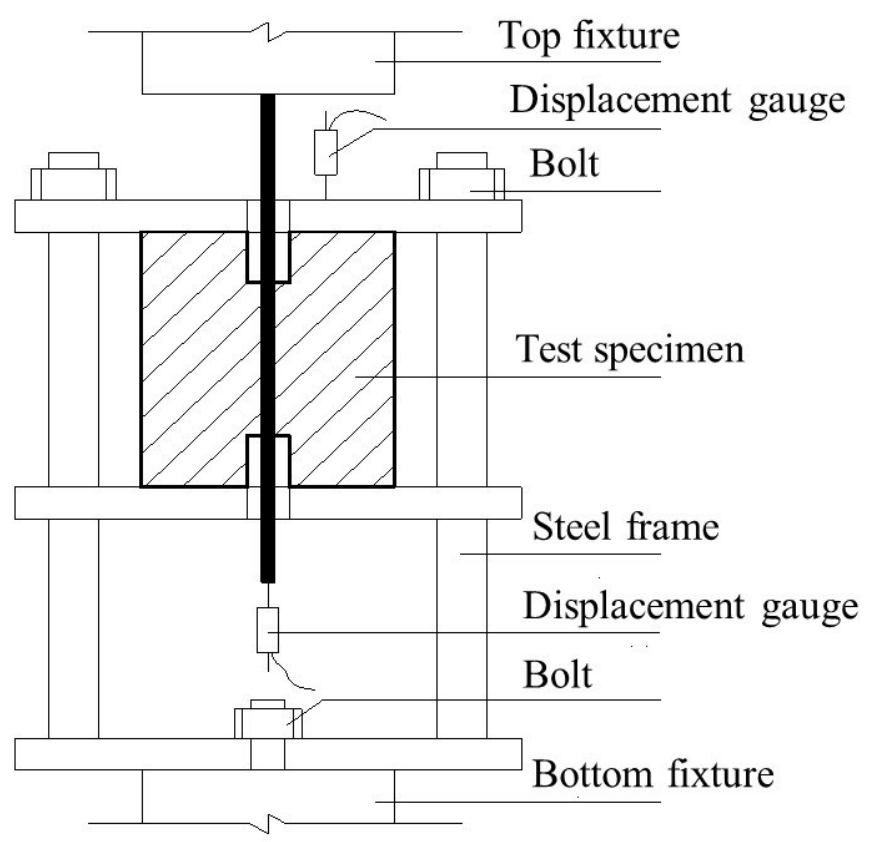

Fig. 3 Experimental set-up for pull-out test.

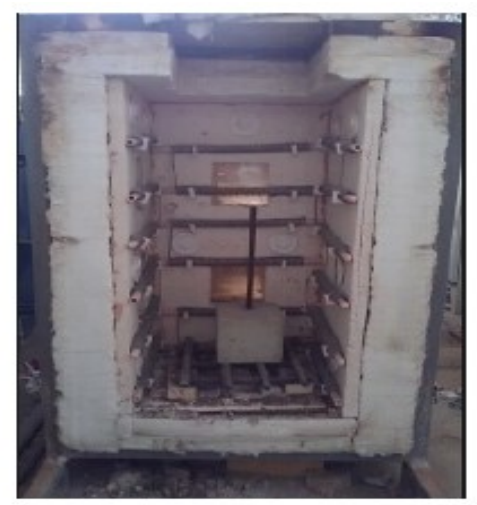

Fig. 4 Heating on specimen.

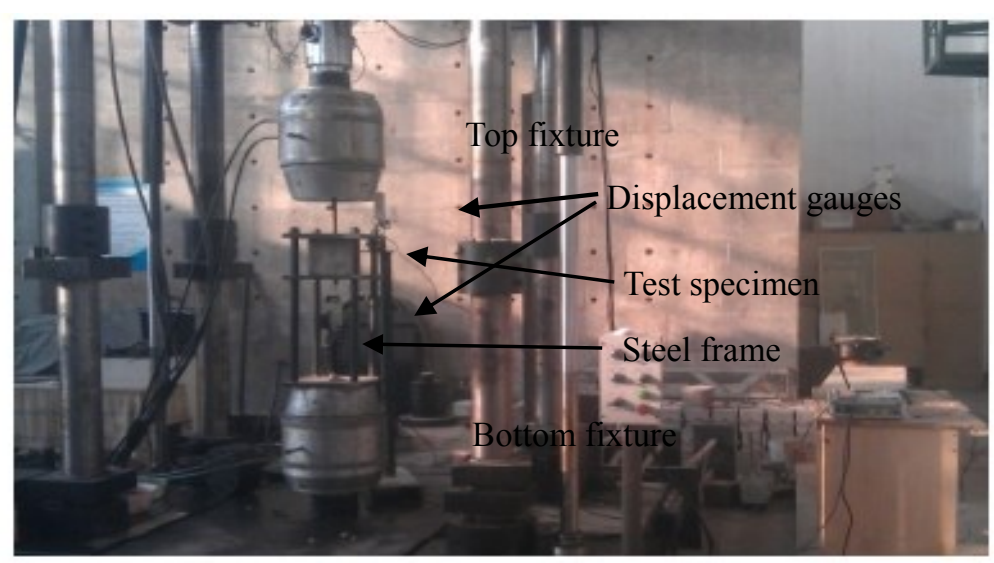

Fig. 5 Loading on specimen. 


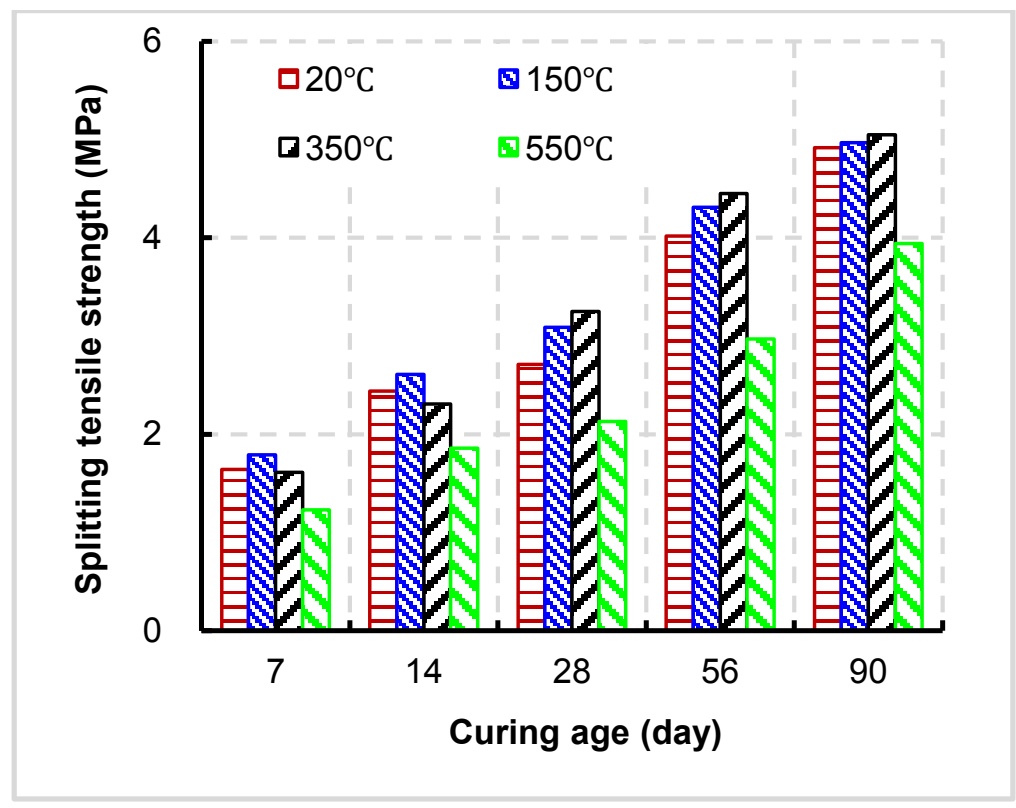

(a) Air cooling

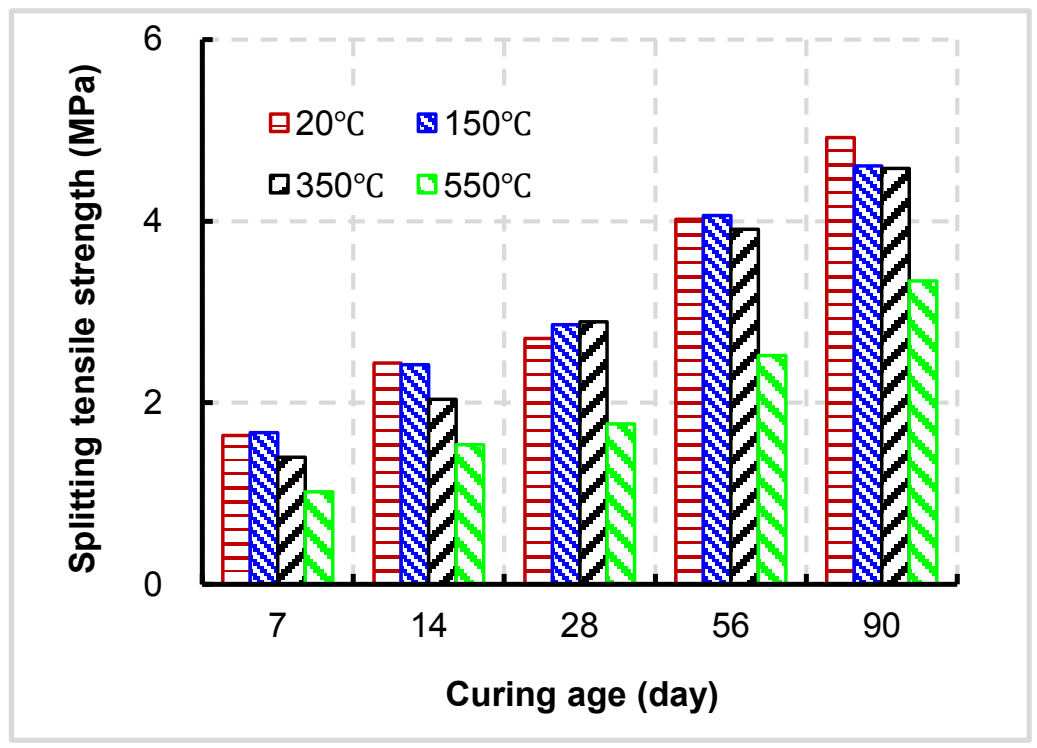

(b) Water cooling

Fig. 6 Residual splitting tensile strengths of flay ash concrete with different curing ages and subjected to different cooling methods after exposed to high temperatures. 


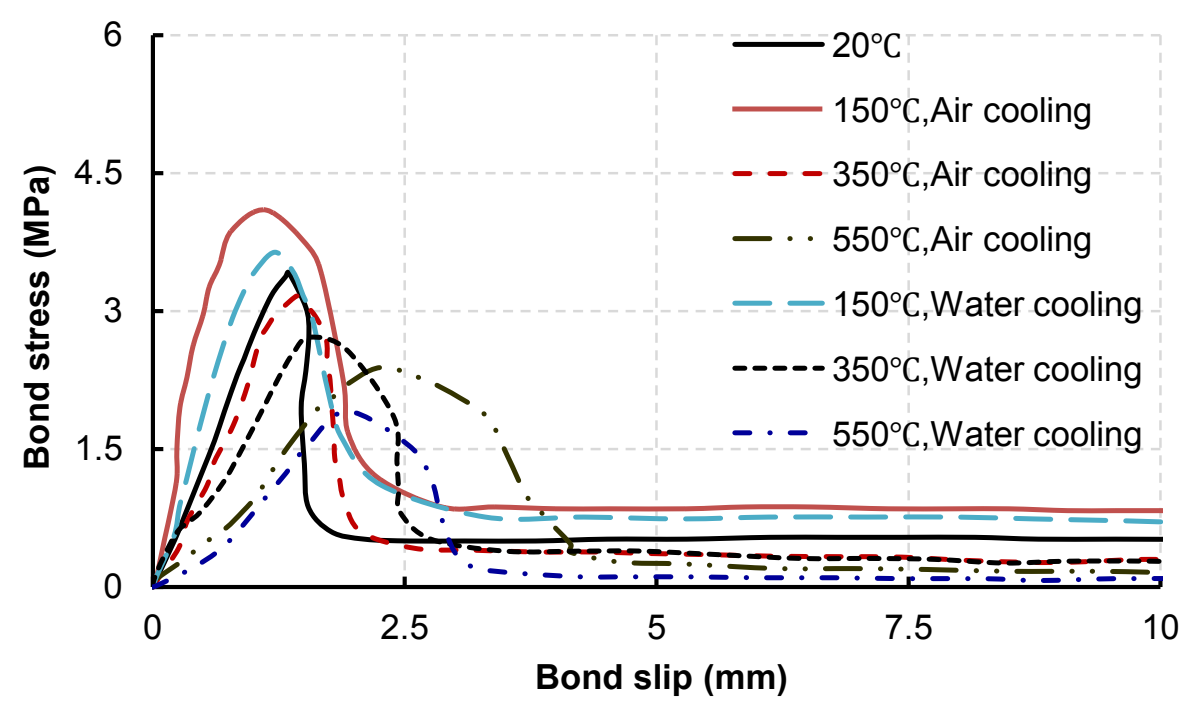

Fig. 7 Bond-slip curves of the specimens with 7 days curing age under different heating and cooling conditions.

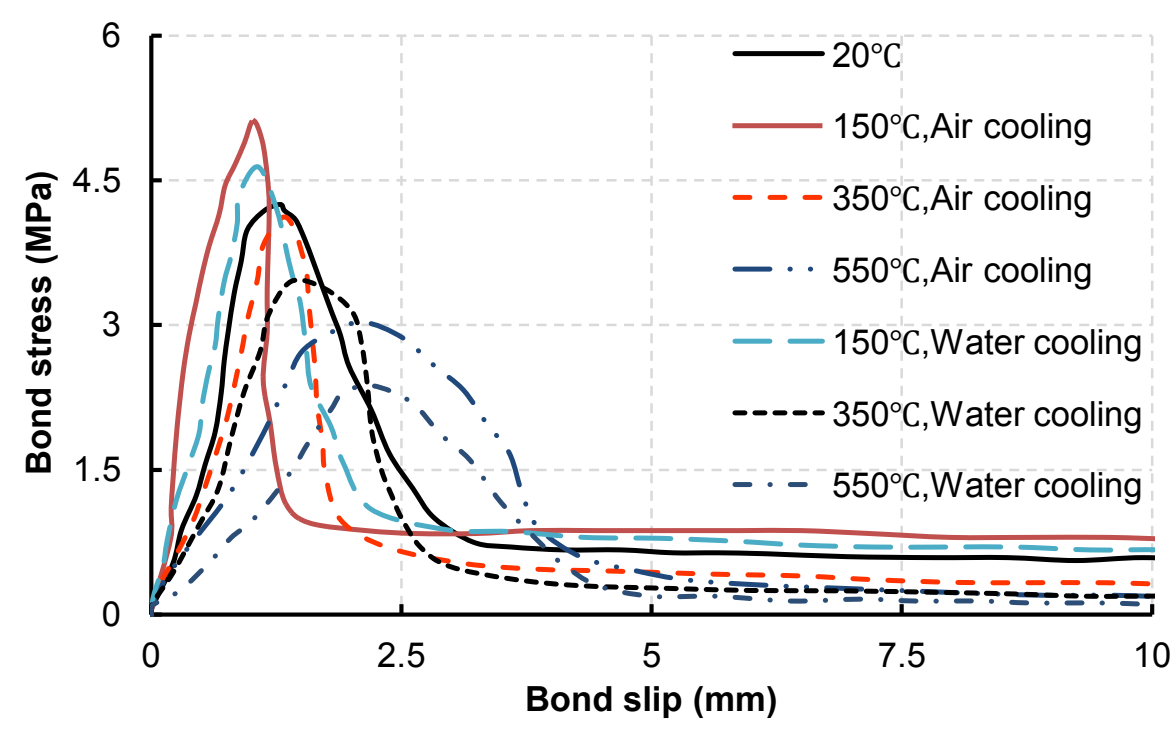

Fig. 8 Bond-slip curves of the specimens with 14 days curing age under different heating and cooling conditions. 


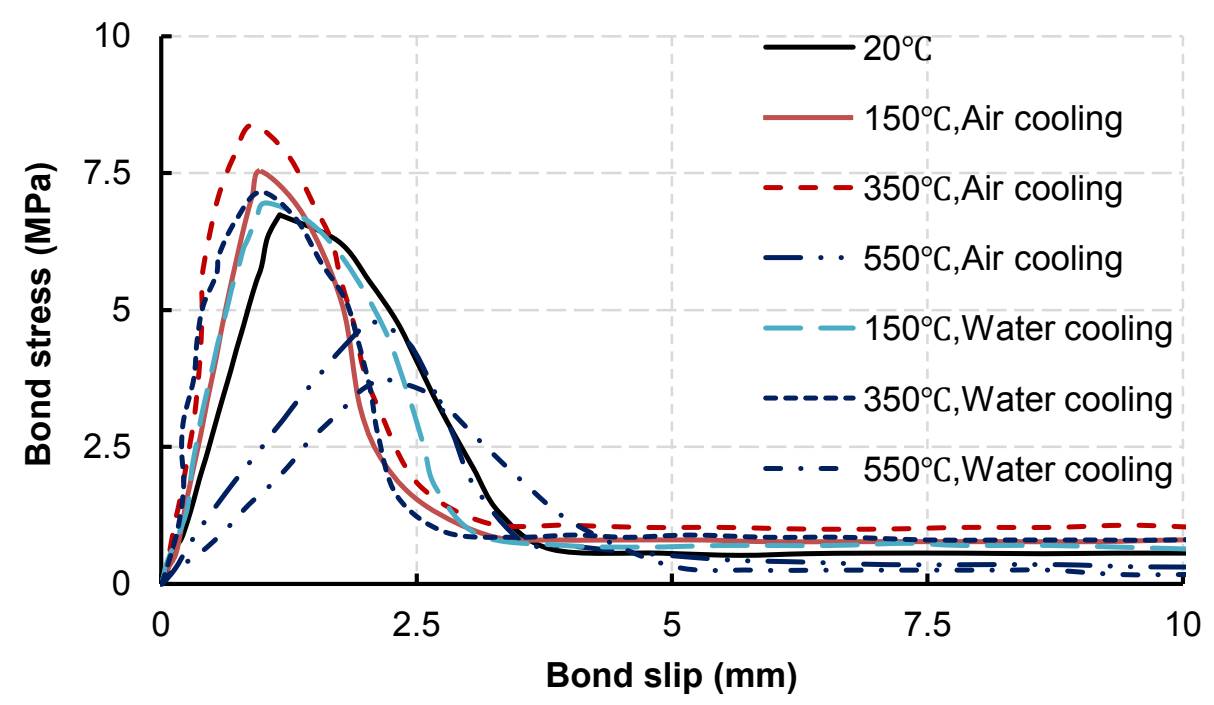

Fig. 9 Bond-slip curves of the specimens with 28 days curing age under different heating and cooling conditions.

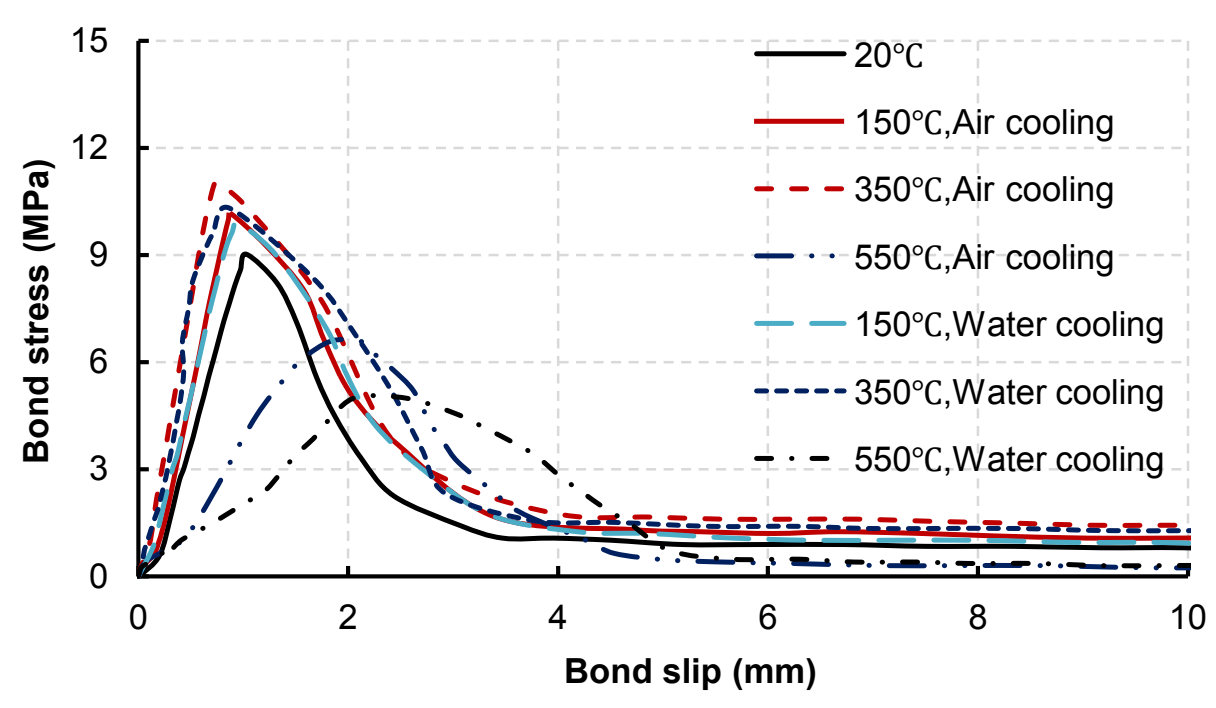

Fig. 10 Bond-slip curves of the specimens with 56 days curing age under different heating and cooling conditions. 


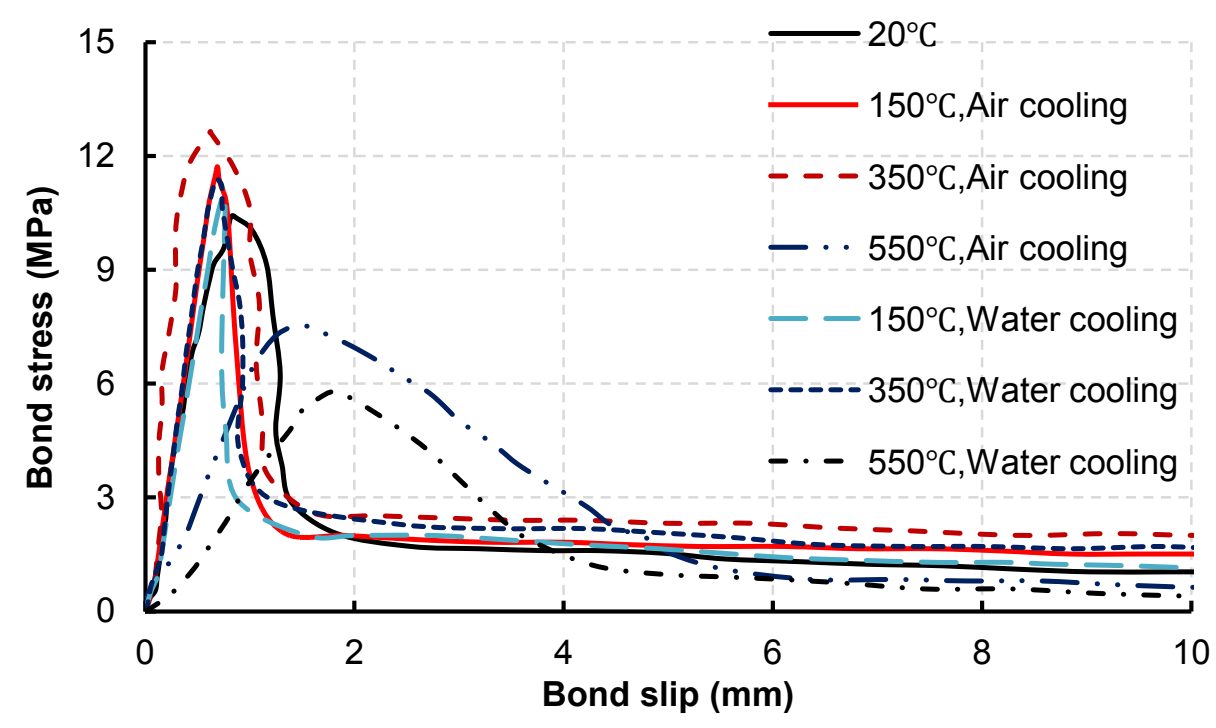

Fig. 11 Bond-slip curves of the specimens with 90 days curing age under different heating and cooling conditions. 


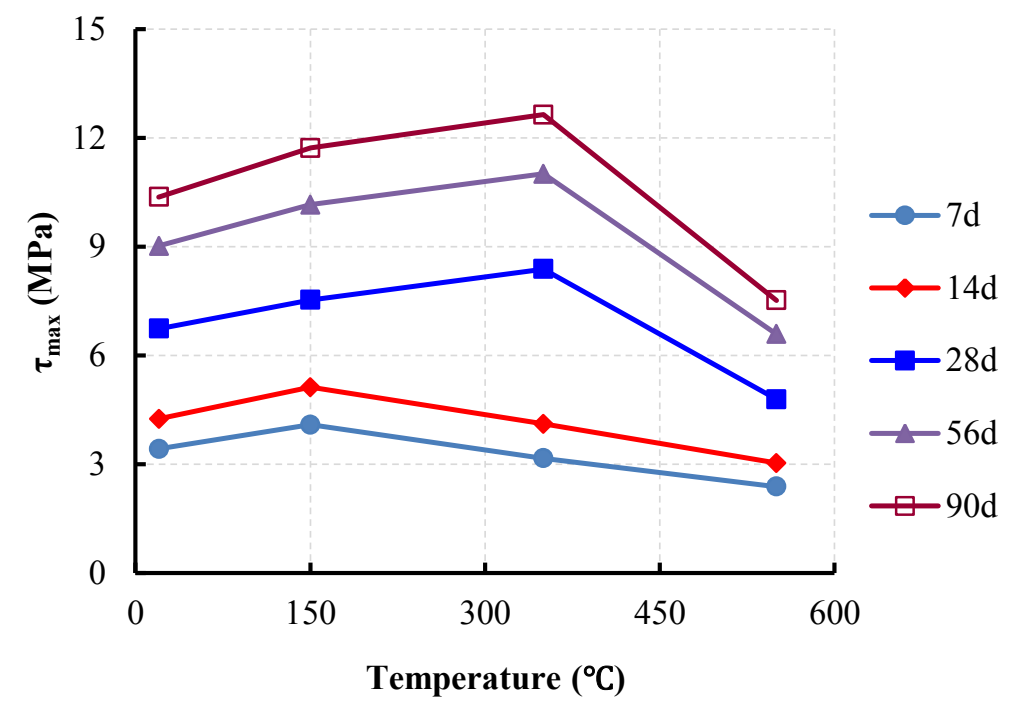

(a) Air cooling

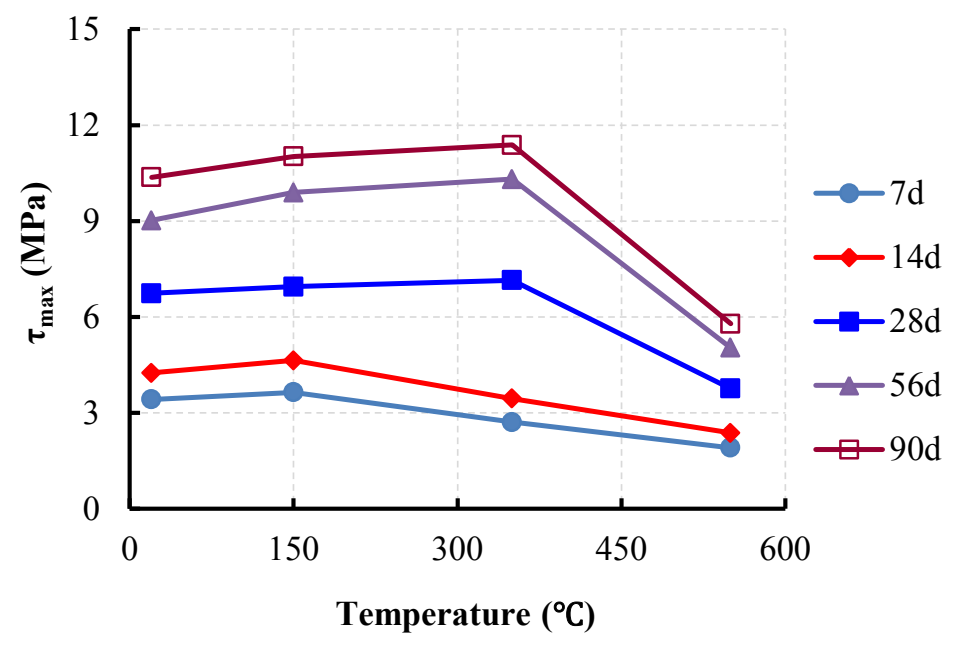

(b) Water cooling

Fig. 12 The ultimate bond stresses of the specimens with different curing ages $(\mathrm{d}=$ days $)$ against temperature. 


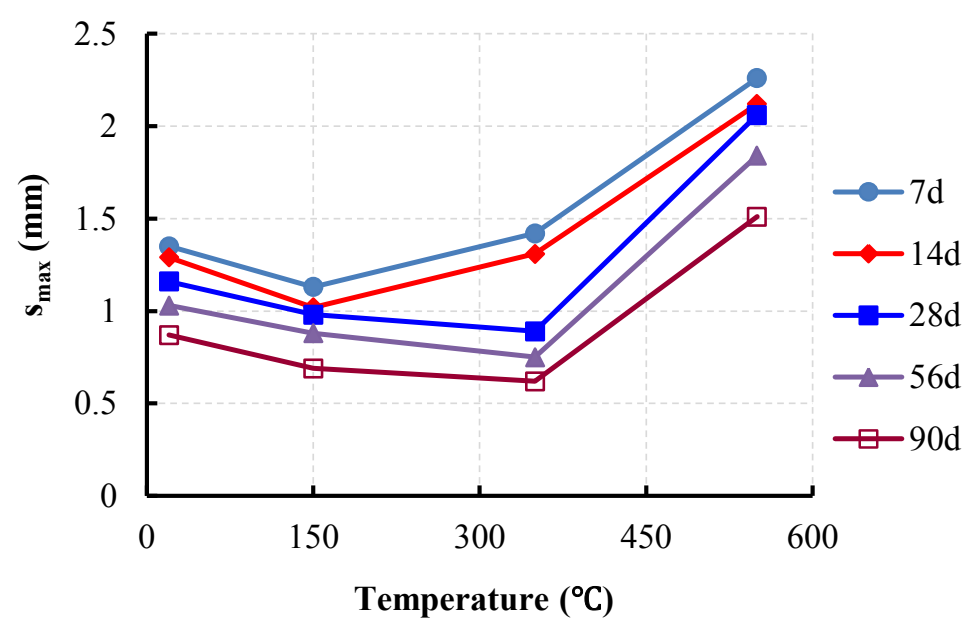

(a) Air cooling

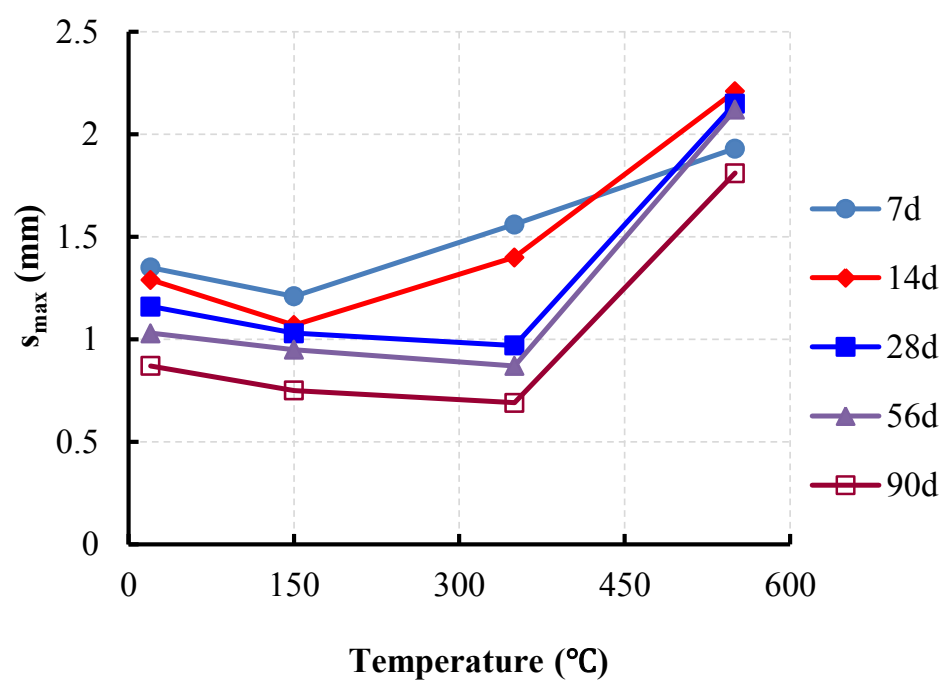

(b) Water cooling

Fig. 13 The ultimate bond slips of the specimens with different curing ages $(d=$ days $)$ against temperature. 


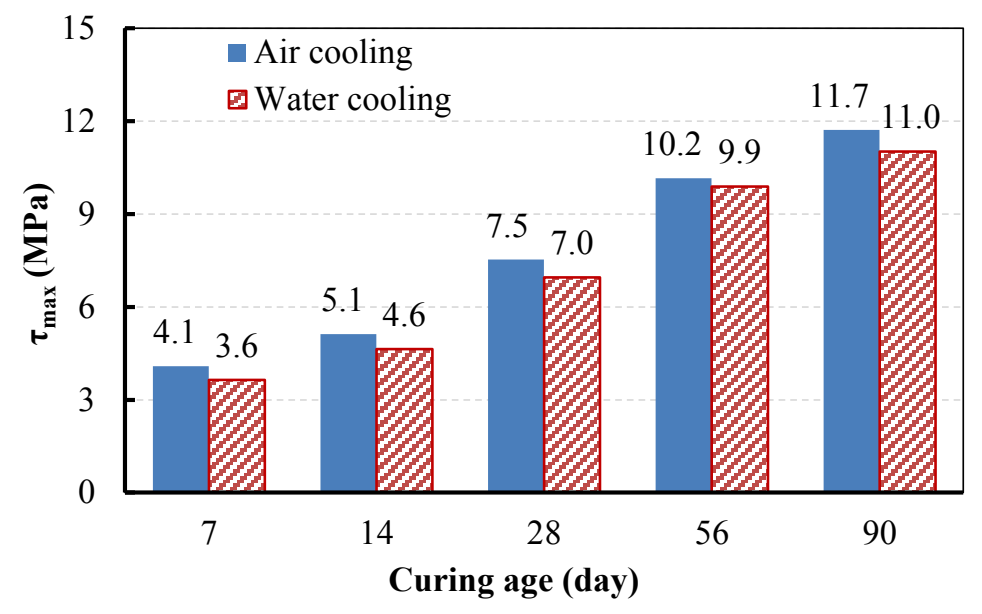

(a) $150^{\circ} \mathrm{C}$

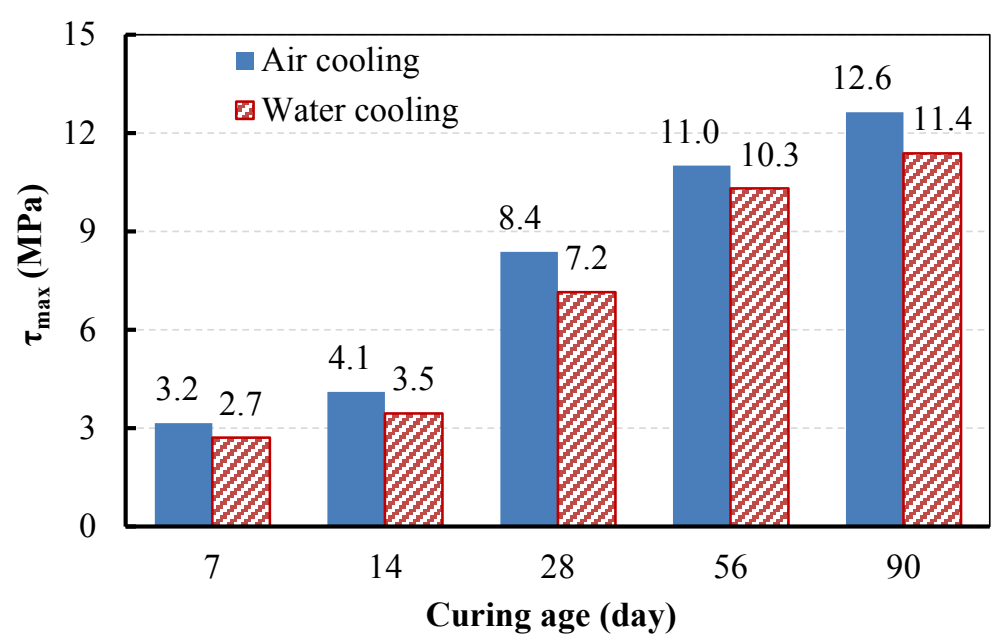

(b) $350^{\circ} \mathrm{C}$

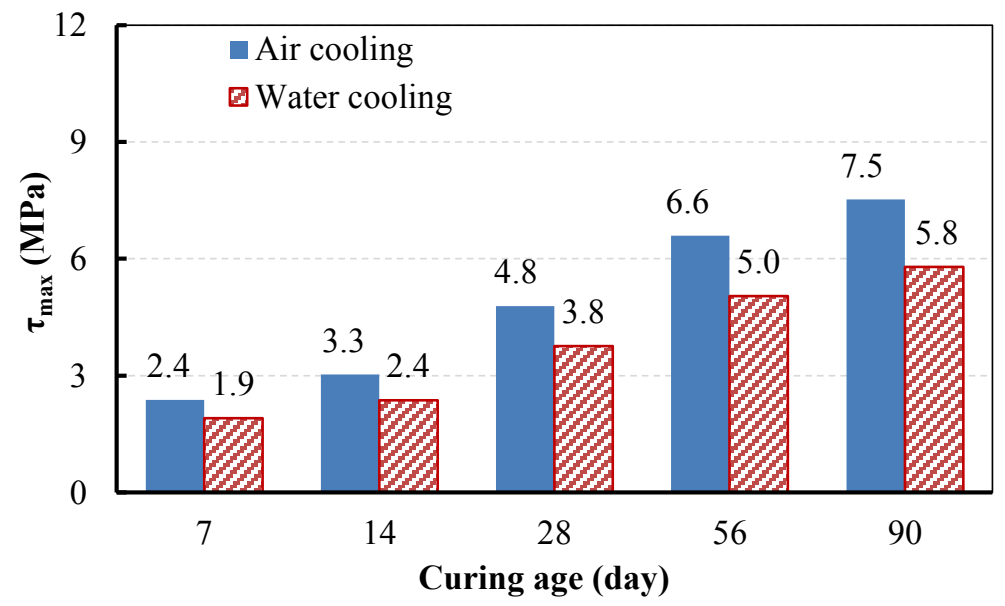

(c) $550^{\circ} \mathrm{C}$

Fig. 14 Influences of cooling methods on the ultimate bond stresses of the specimens under different conditions. 


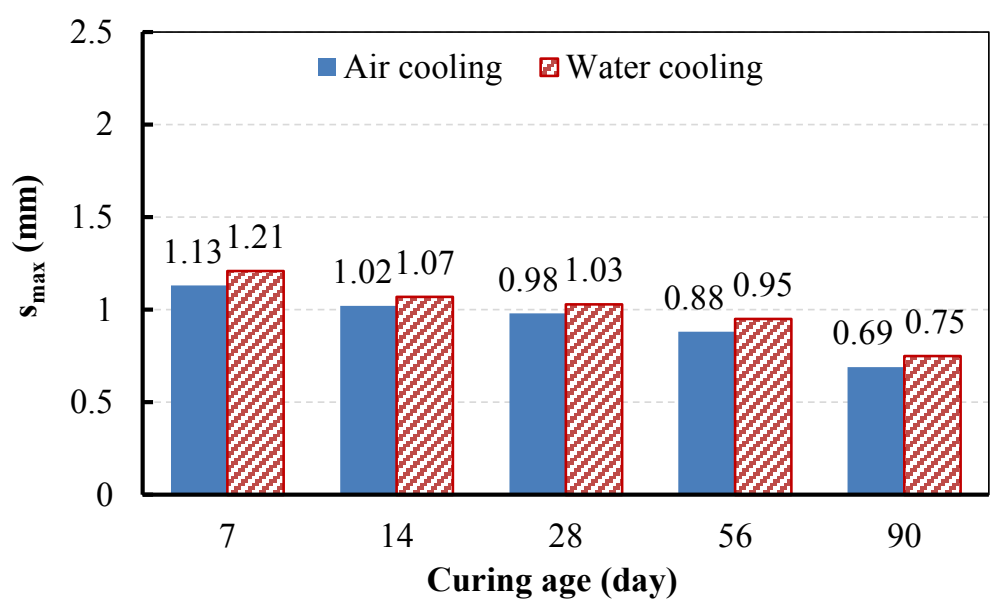

(a) $150^{\circ} \mathrm{C}$

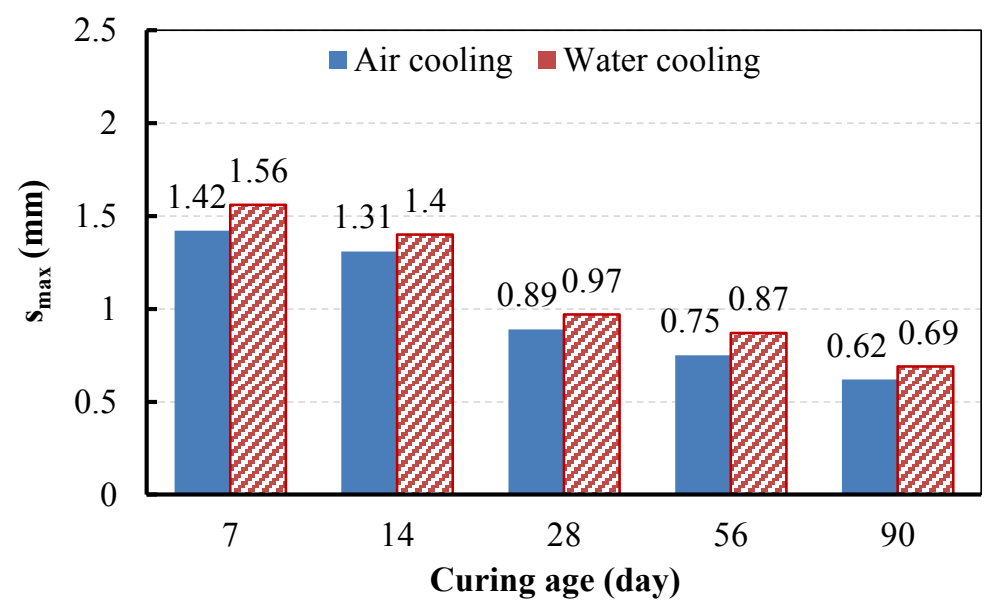

(b) $350^{\circ} \mathrm{C}$

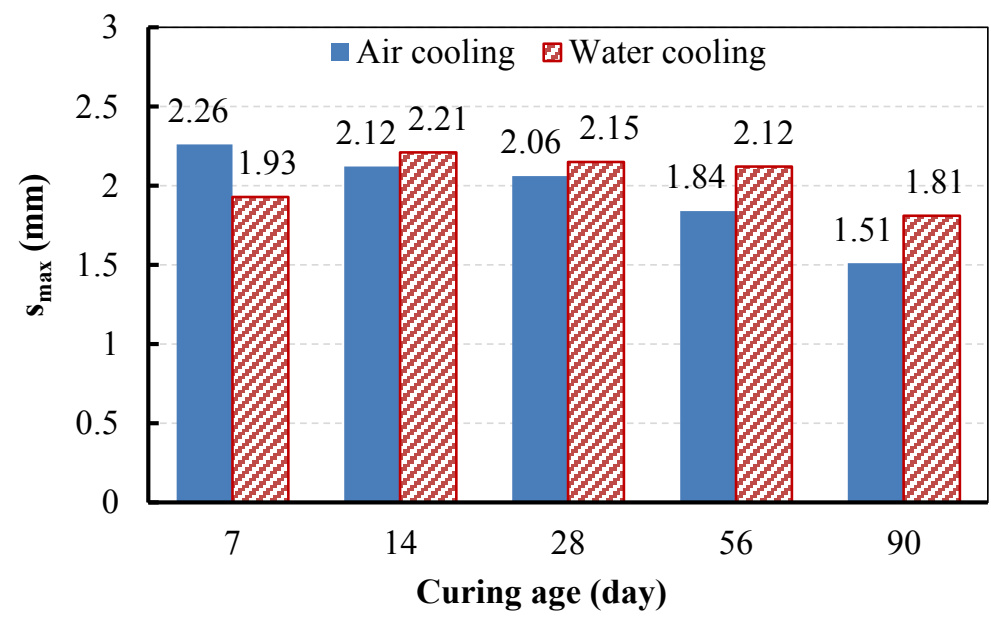

(c) $550^{\circ} \mathrm{C}$

Fig. 15 Influences of cooling methods on the ultimate bond slips of the specimens under different conditions. 


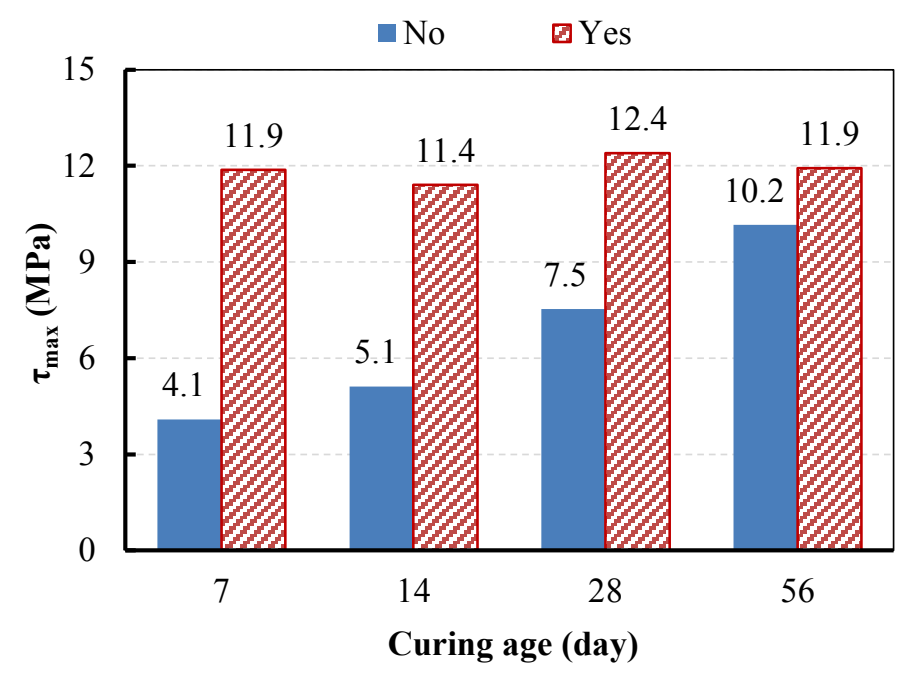

(a) $150^{\circ} \mathrm{C}$

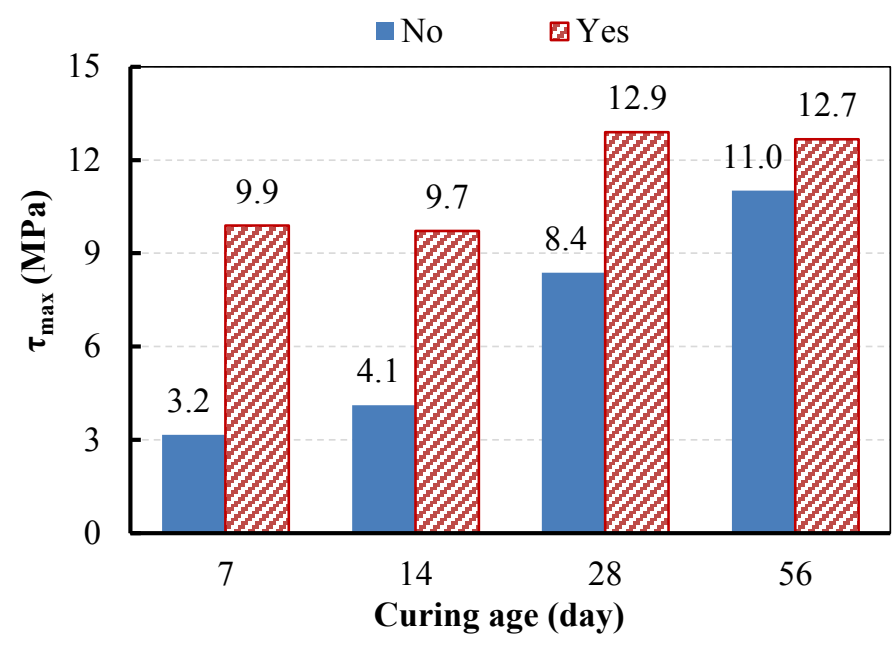

(b) $350^{\circ} \mathrm{C}$

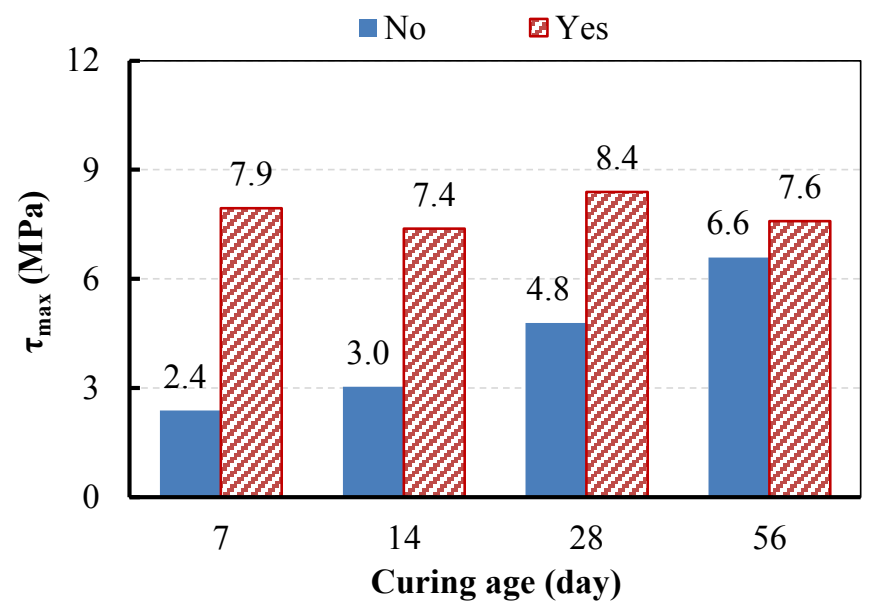

(c) $550^{\circ} \mathrm{C}$

Fig. 16 Influences of standing times on the ultimate bond stresses of the specimens exposed to different temperatures under air cooling ( $\mathrm{No}=$ no standing time; Yes $=$ have standing time). 


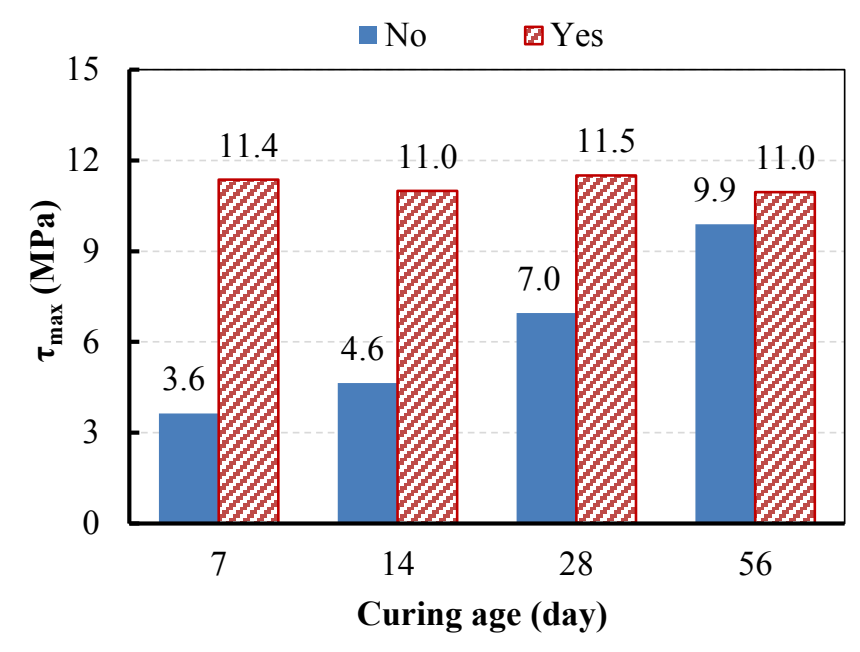

(a) $150^{\circ} \mathrm{C}$

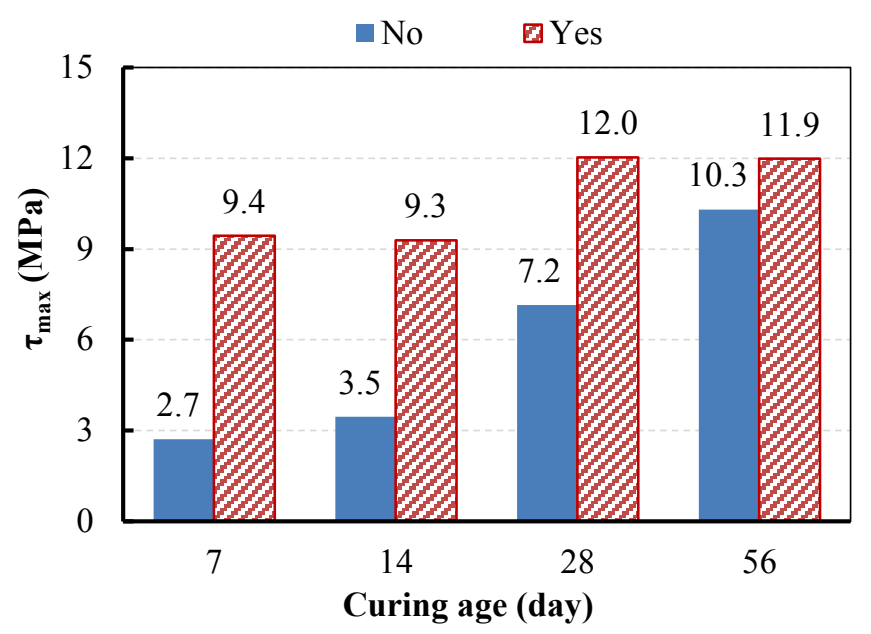

(b) $350^{\circ} \mathrm{C}$

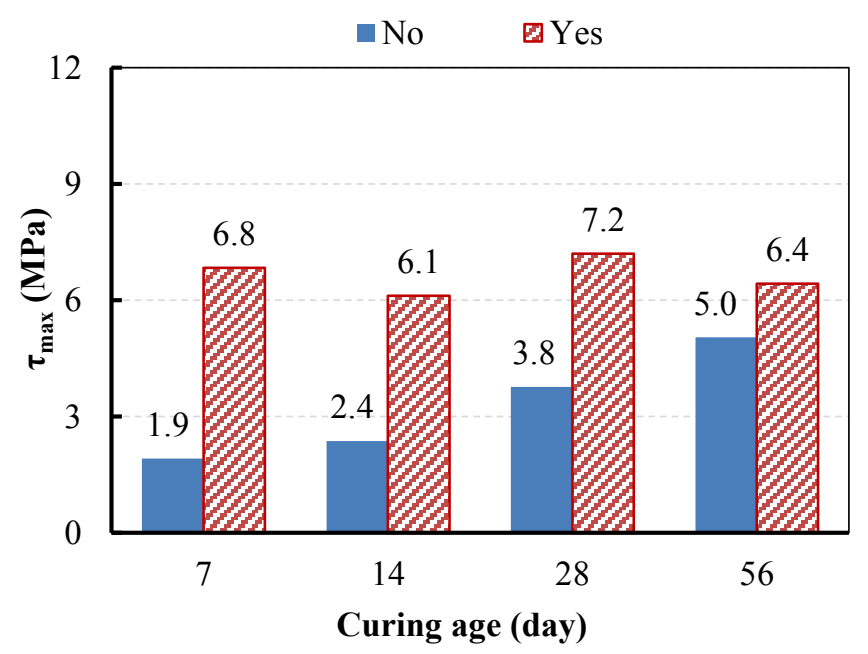

(c) $550^{\circ} \mathrm{C}$

Fig. 17 Influences of standing times on the ultimate bond stresses of the specimens exposed to different temperatures under water cooling $(\mathrm{No}=$ no standing time; Yes $=$ have standing time $)$. 


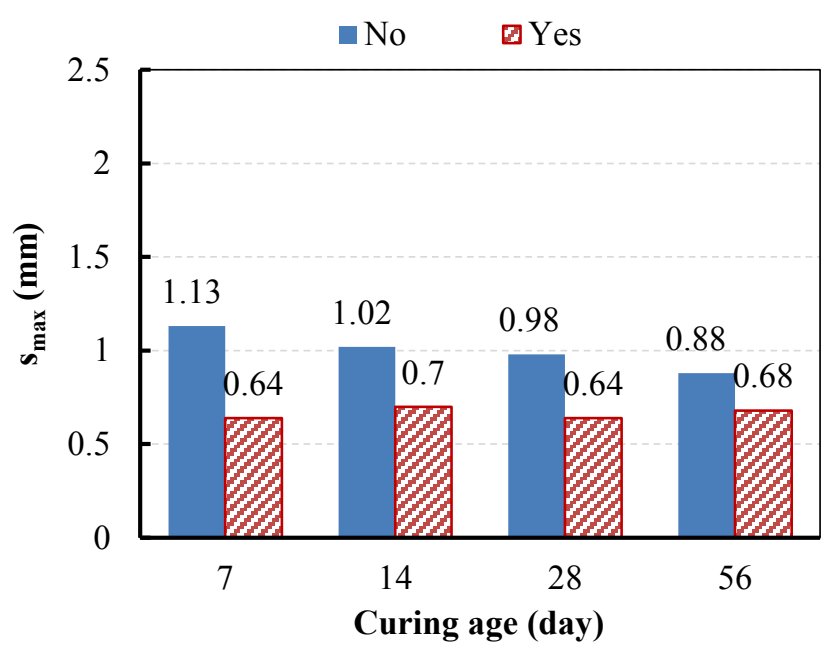

(a) $150^{\circ} \mathrm{C}$

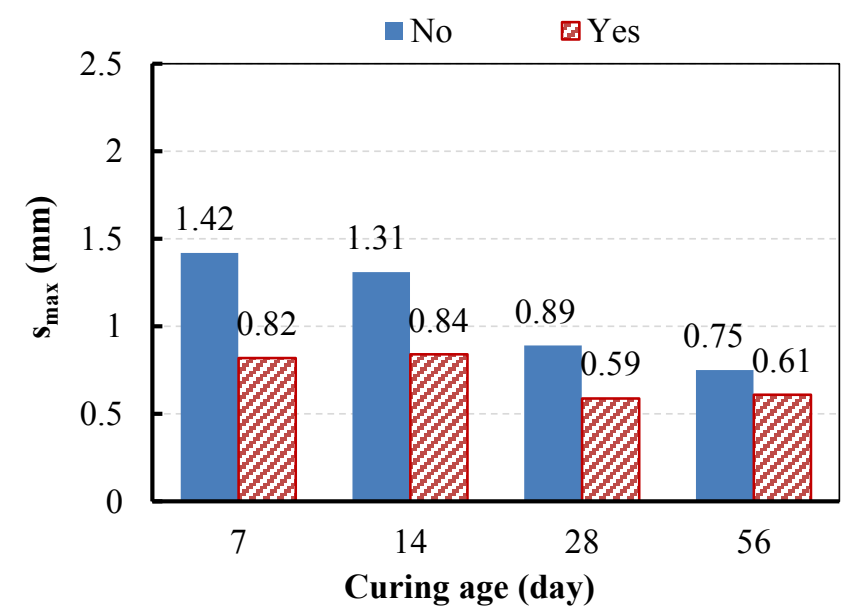

(b) $350^{\circ} \mathrm{C}$

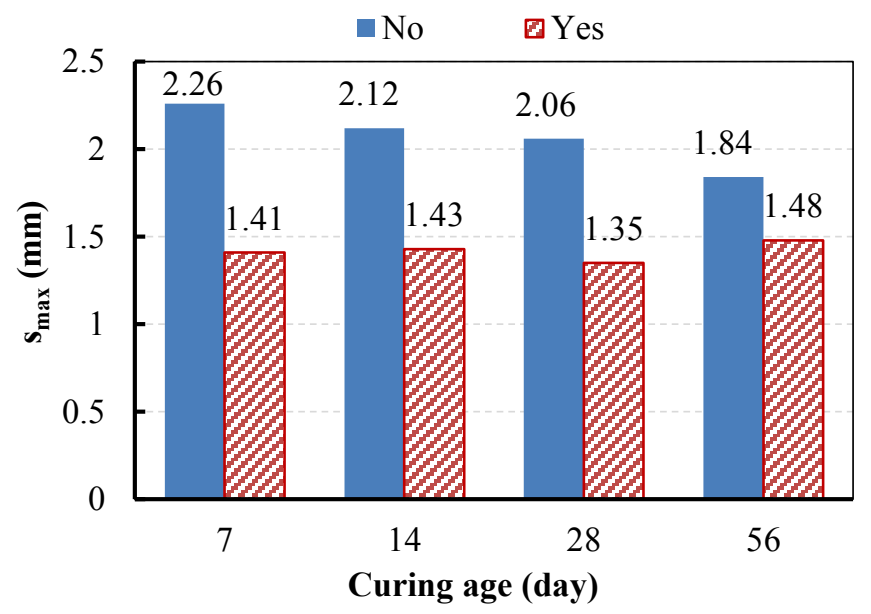

(c) $550^{\circ} \mathrm{C}$

Fig. 18 Influences of standing times on the ultimate bond slips of the specimens exposed to different temperatures under air cooling ( $\mathrm{No}=$ no standing time; Yes $=$ have standing time). 


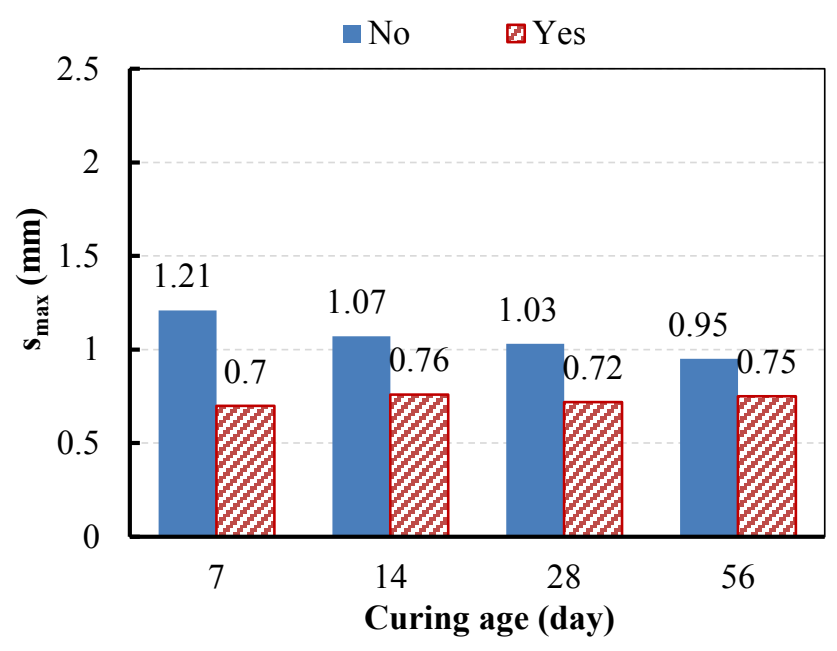

(a) $150{ }^{\circ} \mathrm{C}$

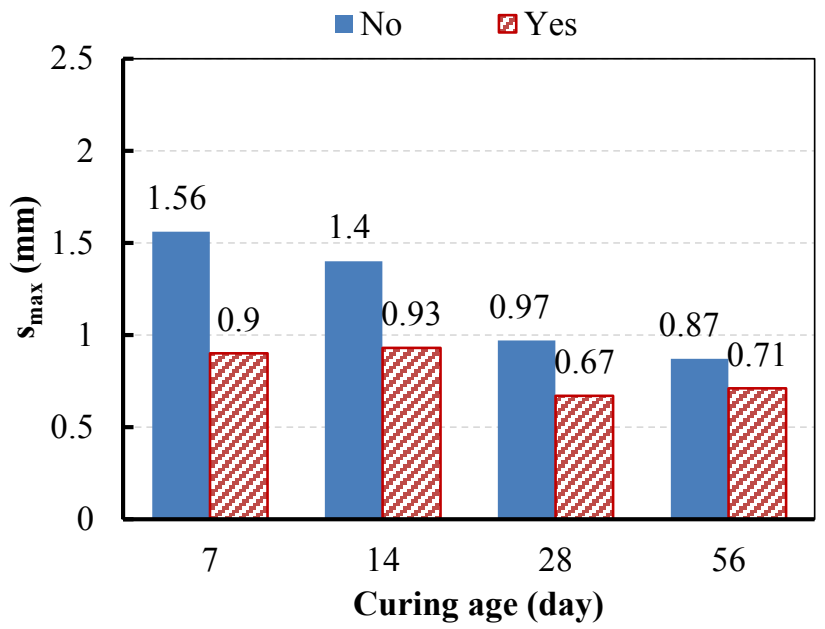

(b) $350^{\circ} \mathrm{C}$

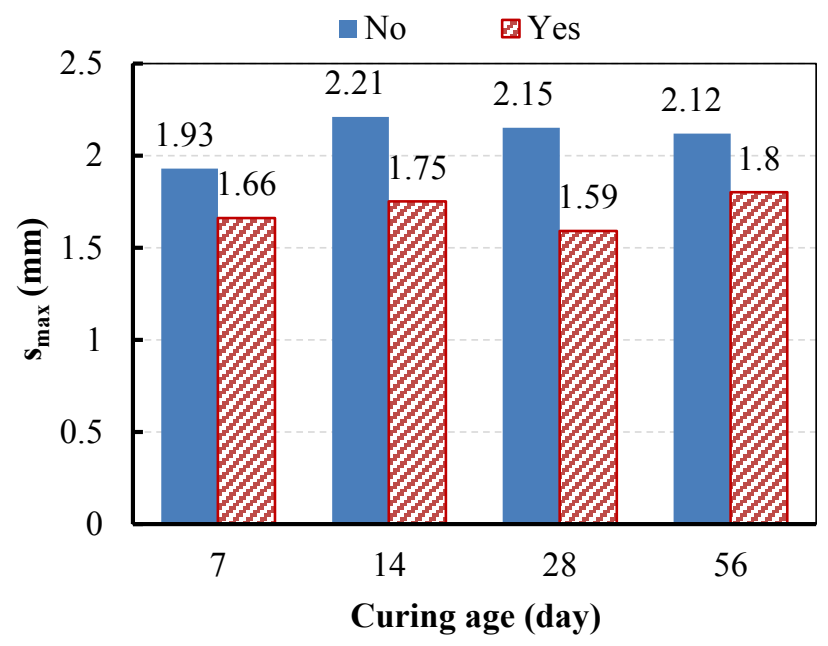

(c) $550{ }^{\circ} \mathrm{C}$

Fig. 19 Influences of standing times on the ultimate bond slips of the specimens exposed to different temperatures under water cooling $(\mathrm{No}=$ no standing time; Yes $=$ have standing time $)$. 